\title{
Against terrorism. Knowledge is power. The contribution of the criminologist
}

\author{
Simona Laura, ${ }^{1}$ Vincenzo Mastronardi, ${ }^{2}$ Monica Calderaro ${ }^{3}$ \\ ${ }^{1}$ Doctor, Criminologist; ${ }^{2}$ Former Director of the Department of Forensic Psychopathology - First Faculty of Medicine - \\ Department of Neurology and Psychiatry Sapienza University of Rome. Director of the master's in criminology criminal \\ system, Forensic Psychopathology, Investigations and Security. Unint - University of International Studies of Rome; \\ ${ }^{3}$ Criminologist. Doctor in Clinical Psychology. Graphologist and teacher responsible for the training course in \\ Graphological Forensic. Sapienza University of Rome. Professor of Psychology and Crime in Social Media at the Unint \\ - Università degli Studi Internazionale di Roma. Researcher International Institute of Criminological and Forensic \\ Psychopathology. Tutor criminological disciplinary area Telematic University of Rome. Unitelma Sapienza, Italy
}

\begin{abstract}
"Terrorism is defined as the series of actions carried out in the context of armed struggles intended not only to attack the opposing armed forces, but to spread fear, distress and insecurity among the civilian populations. Terrorism has always been used to weaken the will resistances of its enemies ". Islamic terrorism has a recent origin. We must start by saying that the use of word Islamic is widespread, but the correct terminology would be Islamist terrorism. It arises from an ideology, in its most extreme meaning and, in this ideology, it finds the greatest justification for carrying out terrorist acts. The core, therefore, is the Islamic fundamentalist religion that justifies, encourages and supports the Jihad. What does Jihad mean? Effort straining towards a purpose. The Quran indicates four ways to lead to Jihad: i) Fight with the heart preceded by a self-purification against sin; ii) Fight with the tongue to preach justice; iii) Fight with the hand in the punishment of sin; iv) Fight with the sword to teach the infidel. What do Sharia (the way) and Khalifa (Caliph) and Shi'a (party) mean? How is tradition, that is the Sunnah, interpreted by the Ulama (wise)? How is the advent of the Mahadi (the Guided) described by the Imams (Imam means the one who precedes)? How can Criminology support? Meanwhile, analyzing the operational mode, then studying the propaganda (central passage of the jihadist phenomenon) to possibly give a hint of what the counter-propaganda of the strategies might be. Propaganda, fundamental issue of cyberwar made by Islamist terrorism, must be studied as propaganda to the masses (through web and production companies), to small groups (in mosques during their sermons and in schools with educational programs reworked and unstructured) and face to face in the process of recruitment and radicalization. It is interesting to look the training and brainwashing processes that are used on the subject, radicalizing to complete the radicalization work. Furthermore, it may be also interesting to analyze the arsenal of Isis, the origin of it and the origin of the weapons. If the analysis of economic flows can lead to the identification of illicit, can the analysis of mental flows lead to the identification, in this case, of the potential jihadist of the recruiting or of the radicalized? Who can be and where could the recruiters be? Do people dedicated to recruitment and radicalization have specific knowledge or are they impromptu people? What can we deduce the response from and for what reason? And who are the people at risk of radicalization? Who could be people already introduced? And what behavior do people already introduced have? And where are they located or where could they be found or where do they think they can meet? And how do they aggregate? And according to their ideology, how could they organize themselves and what could they do? And how could they do it? In this delicate task it will be essential to analyze the profiling of the terrorist, to trace the places with geographical profiling, to have all kinds of information with sociological and cultural profiling, to understand the language, to enter as much as possible in the jihadist culture, to evaluate the type of subject that can be radicalized, to have any kind of information about the radicalized subject, to consider the role of women and the motivation for their involvement, to evaluate enslavement and brainwashing on children and adults. The purpose of this work is to try to enter the mind of the Islamic terrorist or of the potential terrorist in order to bring a contribution, as criminologists, to the mechanism of counternarrative at various levels, to reach a possible help in the mechanism of deradicalization both as intervention of primary prevention (namely, before the process of radicalization begins), secondary (after a process of radicalization has already begun), or tertiary (addressed to subjects towards whom only the abandonment of violent ideology or, at least, the disengagement can be proceeded). The multidisciplinary approach could be the solution to find a way for understanding and to enable the coexistence of various cultures. Islamic culture is a culture far from the Occidental one and requires in-depth studies to be understood and to ensure that its most extreme meaning does not damage the fundamental human rights. The criminology, as a subject of investigation of the mind, can be a key approach of prevention or deradicalization of Islamist terrorism. To penetrate such an intricate and delicate problem, every kind of strength and knowledge is important and fundamental to restore balance, peace and serenity in the world.
\end{abstract}

\section{RIASSUNTO}

"Si definisce terrorismo l'insieme delle azioni compiute nell'ambito di lotte Armate intese non solo a colpire le forze armate avversarie, ma diffondere paura, disagio e insicurezza tra le popolazioni civili. Il terrorismo è stato da sempre usato per indebolire resistenze volontà dei propri nemici". Il terrorismo islamico ha un'origine recente. Dobbiamo premettere che l'uso della parola islamico è di uso corrente, ma la corretta terminologia sarebbe terrorismo islamista. Nasce da un'ideologia, nella sua accezione più estrema, e in questa ideologia trova la giustificazione maggiore per compiere atti terroristici. Il nucleo dunque è la religione islamica fondamentalista che giustifica, incita e sostiene il Jihad. Cosa vuol dire Jihad? Sforzo teso verso uno scopo. Il Corano indica 4 modi per condurre al Jihad: i) combattere con il cuore preceduto da una purificazione di sé contro il peccato; ii) combattere con la lingua per predicare la giustizia; iii) combattere con la mano nella punizione del peccato; iv) combattere con la spada per insegnare agli infedeli. Cosa vuol dire Sharia (la via) e Khalifa (Califfo) e Shi'a (partito)? La tradizione, cioè la Sunnah, come viene interpretata dagli Ulama (sapienti)? Come viene descritto dagli Imam (Imam vuol dire colui che precede) 
l'avvento del Mahadi (il Guidato)? Come la Criminologia può essere di supporto? Intanto analizzando le modalità operative, dunque studiando la propaganda (passaggio centrale del fenomeno jihadista) per, eventualmente, dare uno spunto su quali potrebbero essere le strategie della contropropaganda. La propaganda, nodo fondamentale della cyberwar operata dal terrorismo islamista, deve essere studiata come propaganda alle masse (tramite web e case di produzione), ai piccoli gruppi (nelle moschee durante le prediche e nelle scuole con i programmi scolastici rimaneggiati e destrutturati) e a tu per tu nel processo di reclutamento e radicalizzazione. Interessante prendere visione dei processi di training e di brainwashing che vengono adoperati sul soggetto radicalizzando per portare a termine l'opera di radicalizzazione. Inoltre, può essere interessante analizzare l'arsenale dell'Isis, la provenienza di esso e la provenienza delle munizioni. Se l'analisi dei flussi economici può portare a individuare degli illeciti, l'analisi dei flussi mentali può portare all'individuazione, in questo caso, del potenziale jihadista del reclutando o del radicalizzato? Chi può essere e dove potrebbero essere i reclutatori? Sono persone dedicate al reclutamento e alla radicalizzazione con conoscenze specifiche o sono persone improvvisate? Da cosa si evince la risposta e per quale motivazione? E chi sono le persone a rischio radicalizzazione? Chi potrebbero essere le persone già introdotte? E le persone già introdotte quale comportamento hanno? E dove si trovano o dove si potrebbero trovare o dove pensano di potersi ritrovare? E come si aggregano? E in base alla loro ideologia come potrebbero organizzarsi e cosa potrebbero fare? E come lo potrebbero fare? In questo delicato compito sarà essenziale analizzare il profiling del terrorista, tracciare i luoghi con profiling geografico, avere ogni tipo di informazione con profiling sociologico e culturale, capire il linguaggio, entrare il più possibile nella cultura jihadista, valutare il tipo di soggetto radicalizzabile, avere ogni tipo di informazione sul soggetto radicalizzato, considerare il ruolo delle donne e la motivazione al loro coinvolgimento, valutare la schiavizzazione e il brainwashing sui bambini e sugli adulti. Scopo di questo lavoro vuole essere provare ad entrare nella mente del terrorista islamico o del potenziale terrorista per poter portare un contributo come criminologi nel meccanismo della contronarrativa ai vari livelli fino a giungere ad un possibile aiuto nel meccanismo della deradicalizzazione sia come intervento di prevenzione primaria (cioè prima che il processo di radicalizzazione inizi), secondaria (dopo che un processo di radicalizzazione sia già iniziato), oppure terziaria (rivolta ai soggetti verso cui si potrà procedere soltanto all'abbandono dell'ideologia violenta o perlomeno al disimpegno). L'approccio multidisciplinare potrebbe essere la soluzione alla ricerca di una via per la comprensione e la coesistenza di varie culture. La cultura islamica è una cultura molto lontana da quella occidentale e necessita di studi approfonditi per comprenderla e fare in modo che nella sua accezione più estrema non leda i diritti fondamentali dell'uomo. La criminologia, come materia di indagine della mente, può essere una chiave nell'approccio di prevenzione o deradicalizzazione del fenomeno terroristico islamista. Per addentrarsi in una problematica così intricata e delicata, ogni tipo di forza e conoscenza è importante e fondamentale, allo scopo della restituzione nel mondo di equilibrio, pace e serenità.

\section{RESUMEN}

"El terrorismo se puede definir como el conjunto de acciones llevadas a cabo en el conflicto violento contra las fuerzas armadas, con la intención no solo de atacar a las fuerzas opositoras, sino también de crear un clima de terror e inseguridad susceptible de intimidar la población en general. El terrorismo siempre ha sido empleado para doblegar la voluntad y resistencia de aquel visto como adversario y/o enemigo". El terrorismo islámico es un problema relativamente nuevo. Al mismo tiempo hemos de recordar que la locución islamismo, hoy en día es de uso frequente, en tal sentido cabría decir que la terminología correcta sería terrorismo islamista. Surge de una ideología, en su sentido más extremo, y es en esta ideología que encuentra la debida justificación para cumplir actos terroristas. Por ende, su núcleo es la religión islámica fundamentalista, la cual justifica, incita y apoya la Jihad. ¿Qué significa Jihad? La palabra Jihad se refiere a un esfuerzo para alcanzar un objetivo. El Corán indica 4 modos que conducen al Jihad: i) Lucha con el corazón en nombre de la autopurificación y absolución de los pecados; ii) Lucha con la lengua para predicar la justicia; iii) Lucha con la mano para castigar el pecado; iv) Lucha con la espada para enseñar a los infieles. ¿Qué significa Sharia (el camino) y Khalifa (Califa) y Shi’a (organización-grupo)? ¿Cómo interpretaron la tradición, es decir, la Sunnah, los Ulama (eruditos)? ¿ Cómo describen los Imames (Imam significa el que precede) el advenimiento del Mahadi (el guiado por lo divino)? ¿Cómo la Criminologia puede ser de ayuda? En primer lugar, solo después de haber analizado los métodos de operación, y de haber estudiado la propaganda (eje central del fenómeno jihadista) es posible individuar las posibles estrategias de intervención en tema de contrapropaganda. La propaganda, nudo gordiano de la ciberguerra y medio predilecto a través del cual se alimenta y se difunde el terrorismo islamista, debe ser concebida, estudiada y analizada como el poder de influenciar la actitud de las masas (a través del web y de la producción propagandística), de los grupos pequeños (reunidos en mezquitas durante los sermones y en escuelas con programas escolares reelaborados y desestructurados) y durante el proceso de reclutamiento y radicalización cara a cara. También es interesante tener presente los procesos de entrenamiento y lavado de cerebro que se aplican a los potenciales reclutas para completar el trabajo de radicalización. Así como también sería interesante analizar la procedencia del arsenal y municiones que posee el Isis. Si el análisis de los flujos económicos puede conducir a la individuación e identificación del ilícito económico y de otros delitos conexos ¿El análisis de flujo y estudio de mapas mentales podrían conducir a la identificación del potencial jihadista, del recluta o del radicalizado? ¿Quiénes son y dónde se podrían localizar los reclutadores? ¿Las personas que se dedican al reclutamiento y la radicalización poseen conocimientos específicos o son personas improvisadas? ¿Cuál es la respuesta y por qué? ¿Quiénes son las personas de alto riesgo de radicalización? ¿Quiénes podrían ser las personas ya reclutadas? ¿Cómo se comportan? ¿Generalmente dónde se encuentran, dónde se podrían encontrar o dónde es más factible que se puedan encontrar? ¿Cómo se agrupan? ¿En función de sus ideologías, cómo están organizados y qué pueden hacer? y ¿Cómo podrían hacerlo? En esta delicada tarea será muy esencial analizar el perfil del terrorista, rastrear los lugares a través de sistemas y profiling geográficos, obtener toda la información posible, perfiles sociológicos, culturales, etc., comprender y entender el lenguaje; codigos y formas de expresiones comunes, poder acercarse lo más posible a la cultura yihadista, evaluar el tipo de sujeto que se podría radicalizar, obtener cualquier tipo de información de la persona radicalizada, sobre todo teniendo siempre en cuenta, el papel que juegan las mujeres y las motivaciones que las llevan a participar en modo activo, así como también, considerar y evaluar la esclavitud y el lavado de cerebro en niños y adultos. El objetivo del presente trabajo se centra en la posibilidad de lograr entrar en la mente del terrorista islámico o del potencial terrorista, y como criminologos poder actuar sin demora en los diversos niveles de análisis de los mecanismos de contranarrativa, con la intención de menoscabar el mensaje yihadista, y ofrecer una ayuda concreta y tangible en el proceso de desradicalización como modalidad de prevención primaria (es decir, antes de que inicie el proceso de radicalización), secundario (después de que el proceso de radicalización ha ya comenzado), o terciario (dirigido a sujetos propensos al abandono de la ideología violenta o por lo menos a su renuncia). Un enfoque multidisciplinario es la clave para individuar la via que lleve a la comprención y reconocimiento de la coexistencia de entidades culturales diversas dentro de un mismo Estado. La cultura islámica es una 
cultura muy ajena a la cultura occidental, motivo por el cual requiere un estudio de reflexión más profundo, para poder comprenderla y garantizar que la esencia de su significado más extremo, no dañe los derechos fundamentales del hombre. La criminología, tiene cabida en la investigación de la mente criminal, y como tal, puede ser empleada como llave de lectura en materia de prevención contra la radicalización del fenómeno terrorista de corte islamista. Para poder adentrarse en una perspectiva tan problemática como esta, por el carácter delicado e intricado de las cuestiones que están en juego, todo tipo de esfuerzos y conocimientos es de fundamental importancia para poder donar y restituir a la sociedad civil equilibrio, paz y serenidad.

\section{Introduction}

Islamist terrorism arises at the same time as the Palestinian question and the Iranian revolution after the Afghan war. Initially it had a greater geographical connotation, but subsequently it lost this peculiarity becoming a global phenomenon linked to an ideology, carried forward in the Jihad perspective.

The synthesis of ideology is mainly to fight against every form of Western culture.

The greatest justification for carrying out terrorist acts is found by ISIS in religion. So, the core of Islamist terrorism is in the fundamentalist Islamic religion that justifies, incites and supports the mujahidin or the future mujahidin towards Jihad.

Although we currently understand Islamic terrorism as the Isis phenomenon, we must not forget the existence of similar terrorist organizations which, in this cross-section of history, have acted in the Middle Eastern geographical contexts and which have then correlated, distanced and entered the modern world. The most sadly known:

Al Qaeda: negatively famous for the attack of September 11, 2001.

Present in about 60 countries with the aim of defending Islam from Zionism, from Christianity, from the Occident or from Occidental pro-Muslim governments.

Hamas: been heard in 1987, at the beginning of the first intifada and constitutes its charter in 1988 with encouragement to Israel's destruction.

About Isis, the story intersects with the Nusra front. Its characteristic is a structure, which is the Islamic State, where thought, characteristics and modes of action come together and organize themselves. The danger lies in the ductility and in the impalpability of the Islamic State, which not only lately was a real structure, but a reorganizable mental structure.

\section{Definition of the phenomenon of Islamist terrorism}

Terrorism is defined as the series of actions carried out in the context of armed struggles intended not only to attack the opposing armed forces, but to spread fear, distress and insecurity among the civilian populations. Terrorism has always been used to weaken its enemies' will of resistance ${ }^{1}$.

According to the Bonanate definition of $2001^{2}$, we mean by terrorism "a weapon of those who have not yet been the State, of those who want to become or those who want to destroy the State or the international order with the aim of affirming their own conception of the world and with identifying characteristics". The actions are carried out by people or groups organized against people or acts to provoke a permanent situation of terror with the aim of destabilizing the country, gaining power or overthrowing democratically constituted power, forcing institutions to come to terms and make certain concessions.
Terrorism can be divided into:

- social and political terrorism

- identity nationalist/regionalist/racist terrorism

- religious mystic terrorism.

With the first two forms of terrorism mediations can be planned with negotiations and compromises, with the third form the compromise will be very difficult ${ }^{3}$.

Normally, the concept of terrorism is restricted as an action by irregular groups, normally not framed in the context of military structures, which carry out violent actions and murders against civilians. So, two peculiarities are identified: the political nature of the phenomenon and the systematic use of organized violence.

The violence against which Islamic terrorism occurs is particularly ferocious, enlarged, non-specific and theatrical, such as to induce society into a paralyzing or hysterical terror. It strikes at any time according to logical/non-logical, supported by ideological motivations and religious motivations with similar sectarian methods in recruitment and like in brainwashing, but in a completely different way, publicizing and emphasizing every action, as opposed to other forms of crime where invisibility and silence were and are cornerstones. It goes without saying that the use of any media and a means of propaganda to give maximum resonance is exploited by this type of terrorism. TV, press and web are, therefore, at the service of radicalism. In any case, lately, Islamic terrorism was added and considered to other forms of terrorism (e.g. from Basque terrorism in Spain or terrorism in South America, in this case in Colombia, or the phenomenon of the Red Brigades in Italy, to Jihad limited to Palestine or terrorism in Algeria).

And then it was September 11, 2001.

The threat led to the entire world, while normally the terrorist groups, known up to then, were confined to national instances and did not practice mass murder or threat (1 sit.).

Observing the phenomenon of Islamic terrorism with a sociological approach, the destabilization of the civilian population is a fundamental characteristic. So, the use of violence is aimed at instilling terror and altering the balance using bloody actions such as hijackings, abductions and increasingly sensational attacks.

\section{History of Islamic fundamentalism}

The death of Muhammad, in 632 after Christ, created the origin of a conflict as he did not indicate either the way ("shari'a"), nor the successor.

So, there were fights between the companions of the Prophet

www.diritto.it: "Terrorismo islamico e internazionale".

Bonanate Luigi 2001 definition of terrorism.

Romano Sergio "Anatomia del terrore” Rizzoli edition 2004 page 
(who wanted a successor to be elected among those closest to him) and supporters of the Umayyads (clan of families in Mecca and legitimists opposed to the election of the successor) in favor of a hereditary dynastic axis.

An elective system prevailed, and Abu Bakr was elected and assumed the title of Caliph (Khalifa in Arabic means successor). Omar followed him and then Othman (who was assassinated) and he was succeeded by Alì, cousin and son-in-law of Muhammad. Alì was opposed by members of the aristocracy of the largest Arab cities led by Mu'awiya, belonging to the Umayyads.

Here the division between Sunnis, linked to the Umayyads, and Shiites belonging to the party of Ali (in Arabic party = shi'a) originated. For the Shiites the head of the Muslim community had to be a religious leader (Imam) belonging to the descendants of the Prophet. Contrary to the Sunnis the last prophet was Muhammad and the caliphs were only his vicars ${ }^{4}$. (4 sit.)

The Sunnis represent $90 \%$ of the Islamic universe, while the Shiites represent $10 \%$. Derivation of the word Sunnites is from Sunnah (custom, tradition).

The Sunna is a collection of laws with value equal to the Quran and see the real religious authority in the community, whose leadership is held by the Ulama, plural of Ulim, that is wise. It interprets the divine law based on the study of the Academies of which the most important is that of Al Azhar founded in 971 A.D. in Cairo. The representative figure of the Academy is the Mufti or official jurist.

Central person in the Muslim world is the Imam who has a very different position between Sunnis and Shiites. Imam means the one who precedes and for the Sunnis the Imam is the one who leads the Friday prayer, for the Shiites the Imam is head of the community, guide, wise, interpreter of the dreams of God and Ayatollah (namely, sign of God), a perfect man, the undisputed leader of the political and religious community, to whom the "Isma" belongs, namely impeccability and infallibility.

During history, the Sunnis monopolized political power while the Shiites ruled their Imams, the first 12 of which were direct descendants of Alì.

The theory of the twelfth Imam is important especially for the Shiites. For them, all the Imams died of violent death except the last, said the Waited (Mohammad al Muntazah), son of the eleventh Imam, who disappeared. According to them, he will return to the end of time as "Al Mahadi", he will lead and establish justice and peace throughout the world.

While the Sunnis await the Prophet's teachings (Sunna), the Shiites consider the Ayatollahs as God's offshoots on earth awaiting the last Imam $^{5}$.

This led the Sunnis to accuse the Shiites of heresy and the Shiites to accuse the Sunnis of having given life to extreme sects. The Shiite countries are now Iran, Iraq and Bahrain (5 sit.). Shiite communities are in Yemen, Lebanon, Syria, Pakistan and Saudi Arabia.

While the Sunnis recognize themselves as one group, the Shiites have different factions:

- the Imamites or Duodecimans (Iran) led by theologians called mujtahid, who report the teachings given by the Wakil, agents of the twelfth Imam, educated by him before disappearing.

- the Zaidites (Yemen) according to which to be Imam we must have exceptional qualities, even moral ones. They do not believe in the hidden Imam theory.

- the Ismailis or Settimani divided into further subgroups: the Qarmati (revolutionary communists), the Fatimids claiming descent from Fatima, the daughter of Muhammad. Among the Fatimids we recall the sect of the Druses, esoteric sect, which meets on Thursday instead of Friday with special codes and monogamous marriage. Also, among the Ismailis, we remember the murderers from the Arabic Hashishiya "smokers of violent hashish and conductors of crimes" (4 sit.).

According to historians, today's situation stems from the Iranian revolution of $1979^{6}$, which sent the Shah away by establishing a theocracy in opposition to the Sunni countries.

In 1980, Saddam Hussein's Iraq invaded Iran, resulting in a bloody war that ended in 1988. There were two factions. On one side the Sunni countries headed by Saudi Arabia, opposed to the Shiite countries. But Iran was an ally of Syria, a country led by Shiites, albeit a majority Sunni. Iran and Syria were supporters of the Lebanese Shiite Hezbollah Movement, operating in southern Lebanon, with the only objective to destroy Israel. Iran, Syria and Hezbollah formed the Shia crescent. So, Syria has counted as allies Hezbollah on the border with Lebanon and Iran that has supported it with soldiers and weapons. Russia was a political ally of Syria. This faction was opposed to the other formed by Egypt and Saudi Arabia (allied with the United States) majority Sunni.

In all this fits terrorism. Hezbollah is a Shiite militia. Al Qaeda and ISIS are composed of radical Sunnis. The Syrian government of Assad is opposed by moderate rebels and Sunni militias (including the Al Nusra Front, a group representing Al Qaeda in Syria). ISIS also fights to bring down the Assad government, with possible greater Sunni penetration into Syria. And then we have the terrorist group of Hamas, widespread in Palestine, Sunni inspired, that receives aid from Iran as the main enemy of Israel. In the Middle East, both the Sunni faction and the Shiite faction have used severe religious principles as a pretext to hate and blame. I quote the words of Seyed Ali Faldullah, a Lebanese Shiite official, who are able to summarize the reason for the clashes: “... differences in doctrine are used because they have a very effective impact. If you invite your people to fight for international regional dominance, nobody will come. But people act when they are told that their religious Sect is under attack or that their sacred places are about to be destroyed. ...". With these words we can understand the origin and tendency of Middle Eastern conflicts.

In the Islamic doctrine the word "Jihad" means effort aimed to a purpose. There is a higher Jihad in the improvement of the believer and a lower Jihad for the Muslims who do not follow the Sunnah.

In the times of orthodoxy both Jews and Catholics living in Muslim lands could choose whether to convert to the religion of Allah or pay a tax to obtain a protected status (Dhimmi).

Being the Jihad one of the duties of the good believer, apparently there would be no connection with foreign peoples. In the Occidental world it is usually meant by Jihad terrorist, disguised as Holy War.

The Quran indicates four ways to lead to Jihad:

- Fight with the heart, preceded by a self-purification against sin Fight with the tongue, to preach justice

Fight with the hand in the punishment of sin

Fight with the sword, to teach the infidel.

At this point we must make a distinction between the Occidental law and the Islamic law ${ }^{7}$. The goal of Occidental law is to guarantee the rights of individuals to life, property and peace while the goal of Islam is to achieve eternal salvation, so much so that "Sharia"
www.studiarapido.it
www.ilpost.it
www.ilpost.it
Oasis n. 23: "il Corano e i suoi custodi". Editors Marsilio June 22nd 
means a straight path that is a conduct that the Muslim must follow to ensure salvation (6 bibl.).

One consideration for the Islamic belief is that it is characterized by a direct relationship between Allah and the people, without intermediation of priestly corporations, but only by individual interpreters of the Quran (Scholars) ${ }^{8}$.

So, to summarize the main currents of Islam are:

The Sunnis: their fundamental beliefs are:

- Allah is the God and Muhammad and his prophet (shahada)

- Prayer rituals 5 times a day (salat)

- Donation to the less fortunate (zakat)

- Ramadan observation (sawn)

- At least once the pilgrimage to Mecca (hajj).

The Shiites or followers of Ali consider the fundamental importance of the Imam as absolute authority. And from them various other currents branch off, which we can gather together in the schismatics.

Attention to the etymology of the words of this creed:

"Muslim" means one who is subject to Allah.

"Quran" means recitation and is the text that said Allah to Muhammad through the Archangel Gabriel.

The Law or Way to be pursued (Sharia) is formed mainly by the Quran but also by law collections (Hedith) collected in Sunnah, whose etymology is "customary".

According to the Muslims, when Jewish sacred texts and the Gospel diverged from the Quran, it was because they were manipulated by Jews and Catholics.

In a magazine of the Islamic State ${ }^{8}$, the DABIQ, there is an exhortation to the "infidel" to "break the Cross" and a message to the Christians. They offer two options: either "death in a useless and infinite war against the Islamic state" or "conversion to Islam". With the latter you can enter the "Gardens of Paradise".

\section{Endogen and exogenous terrorism}

Al Qaeda and ISIS are different and competing terrorist organizations, often confused among themselves ${ }^{9}$.

ISIS was born from a split with Al Qaeda in Syria. The ISIS faction operated in Iraq and was called AQI. There was a disagreement among the leaders for strategies, methods and goals. They had only one common goal: the creation of the Islamic State. According to Al Qaeda the creation of the Islamic State is in progress and to found it, it is necessary to hit the enemies hard so that the population converts. ISIS believes that the Islamic State is already in place, the Caliphate is existing and any threat to the existence of this state determines and justifies the violent action of the good Muslim to rush into the defense of the state. The propaganda capacity and the fascination of the message made the ISIS to overwhelm Al Qaeda.

The cruelty of ISIS, which uses extreme theology, comes to kill other Muslims as well. This is one of the critical division points between ISIS and Al Qaeda that sees United States or Saudi Arabia as enemy states.

With the will to establish the Islamic State, people living in Muslim territories but of different religions were oppressed when they refused to convert to the Muslim religion ${ }^{10}$. Directly forced to leave the territory with assets and belongings, driven from their homes, deprived of rights, targeted by extortion, humiliated or in danger of being murdered did not find (and even do not find) another way better than emigration. Even ancient religious minorities are persecuted in the name of the institution of an Islamic State (such as the Yazidis living in Iraq border with Syria).

According to the report of the ACS foundation on religious freedom in the world, compared to the years $2012 / 2014$, there is a high emigration, probably linked to Islamic extremism, in 5 countries: Saudi Arabia, Iran, Iraq, Syria and Egypt. Migration flows affect modern Europe and now they are trying to characterize these people not so much by their nationality but by their religion. Not for this reason we want to compare migrants to terrorists, even if part of the terrorists exploited illegal immigration to reach Europe.

I consider important in this thesis also to frame the historical, economic, political, cultural moment in which a certain phenomenology is occurring and, in this case, the terrorist one. Part of terrorists come from European countries and through a process of radicalization they have converted to Islam. They are normally second generations of migrants who arrived in Europe in the mid-1900s.

I will try to understand for what reason these young people have converted to such a radical form of Islam and to focus on different causes. Observing the living conditions of young second/third generation Muslims we can see that they can feel frustrated because their belonging families are concentrated in certain areas, almost like a sort of ghettoization. They are normally unemployed without prospects and are more easily entangled in the processes of radicalization with identification in a group whose sole objective is adherence to "authentic Islam" and to Jihad.

With a phenomenological analysis, we are therefore facing a Muslim fringe that uses violence and terror by name and on behalf of religion to establish a sovereign Islamic state with its own rules.

And it comes both from the territories of natural belonging, both from within the nations themselves that suffer bloody attacks.

So, the paradox is that the same people who live in a particular country can organize themselves, affiliating themselves to external structures, to harm the same nation in which they were born and, in some way, accepted.

\section{The Islamic state}

On June 29, 2014 in the Mosul Mosque, Abu Bakr al Baghdadi, founded the Islamic State of Iraq and the Levant, although the creation was far earlier ${ }^{11}$.

Hillary Clinton in "Hard Choices" writes about the US support in the ISIS Constitution with an agreement signed on $13^{\text {th }}$ May 2013.

The Islamic State is a state with objectives, an army, people, a currency, a legislative body, an educational path, a collection of taxes. And it tries to recruit all people looking for a single Ummah. It makes no distinction of race, giving job opportunities, career, not forgetting the fringe of weaker population. It does not intend to take hostages (I observe how difficult it is to negotiate) but wants to fulfill Allah's promise. The Islamic State has its fundamental point in the will to spread the ideology. And this diffusion is through video, initially created in a very rough way with long recitation of the verses of the Koran (2006), up to a real production (starting from 2012) made and generated by specific technicians with the purpose of informing about the ideals of the Islamic State and then subsequently recruit.

www.gliocchidellaguerra.it August 2nd 2016.

www.ilpost.it $11212015>$ Al Qaeda Isis.

10 Fondation Ismu: "Ventunesimo rapporto sulle migrazioni 2015 Franco Angeli". Page 21 - 26 Edizioni Digitali.

11 The Islamic State. Lo Stato Islamico. A. Albanese, G. Fanciullo, E. Molle, R. Baretsky, G. Balkan, E. Valdenassi. GAP 2014. 
The shocking thing is that to have this technical ability in filmography foreign technicians have been paid, and the methods of exposure are very similar to those used by the United States in the advertising campaign for their military actions.

The name ISIS is an acronym of the Islamic State of Iraq and Syria. ISIL is used interchangeably as an Islamic State of Iraq and the Levant (where expansion intentions are noted). The acronym used in the countries of origin is DA'ASH (Ad - Dawlah al Islamiyah).

We will see later in this chapter, a profiling the historical sociological base where it was born the breeding ground for the start of ISIS.

In this chapter, however, I must emphasize a reflection by a Saudi daily Asharq al Awsat (www.aawsat.com) signed by Ghassan Al Imam and reported by Albanese et al. in the book "The Islamic State". He says to Imam: “... The successes of ISIS must be compared and opposed to those of the contemporary Arab system, since the Arab countries have achieved independence between 1940 and 1950. Politically speaking, I said and continue to say that the Arab system was born with independence. His ambitions were limited to the creation of an Arab League rather than to the creation of a Union of Arab societies. Over time, the ambitions expressed in the rhetoric of the Arab League and in most of the Arab regimes have diminished and we have begun to talk about Arab peoples rather than Arab Nation. This rhetoric has paved the way for social disintegration, sectarian strife and the emergence of ISIS-like groups". Ghassan al-Imam says again, speaking of ISIS, which "is not up to Arab nationalist ambitions. The error of the historical Islamic Caliphate (Umayyad and Abbasid) is being repeated, whose inertia and anti-democratic character have led to the outbreak of a bitter struggle of power between Arabs and non-Arabs. The struggle ended with the affirmation of Mamluk, Turkish power in the Arab lands, weakening the sense of belonging to the Arab nation, almost destroying the language, culture and literary heritage with religious slogans."

So, the propaganda made by ISIS for unity in the name of the Islamic State puts the Arab world at risk. But it is true that no Muslim unity is possible without the Arab one, for which fights are added but it is not the subject of this article.

As in every state, even in the Islamic one there is a hierarchy.

ISIS is structured in such a horizontal way that it can interchange or regenerate if one of the leaders is the victim of a war action $^{12}$.

There is a chief of ISIS or Caliph who owns an escort, two Deputy Caliphs, with merely pragmatic and administrative function responsible of disclosures to local governors and thus to local councils on how to implement the decrees of the executive ${ }^{13}$.

The Islamic State, in fact, has several provinces called Wilayat, each governed by a Governor called Waly, responsible for a local structure. The Governor is supported by a Military Commander, an Administrative Minister, a Minister of Financial Affairs, and a Minister of Security.

In order of importance:

the Political - Religious Council or Council of Shura who has the decision - making power on who becomes a Caliph (must descend from the tribe of Muhammad, i.e. from the tribe of $\mathrm{Al}$ Quraysh)

- the Military Council with Military Leaders. Below the military leaders there are departments that deal with propaganda, funding, justice, weapons, intelligence and religion. The military structure of the Islamic State is divided into Divisions (FARQA), Brigades (LIWA), Battalions (KATIBA).

- the Security Council (Amn) and Intelligence ${ }^{14}$.
The decisions are conveyed by the Council to the Caliph. If the Caliph's answer is positive, the departments take care of the operational phase.

Since 2014, the Islamic State has issued its passport creating stamps for foreign passports and has plans to release its identity document (Jinsiya).

The strength of the Islamic State is the establishment of a system of repression of very heavy common crimes in the governed lands. The civilian population that before the entrance of the Islamic State was constantly in fear of danger, if it lives in the lands of Daesh and if it observes slavishly the rules in the Caliphate has the possibility of living in "security" (there are numerous propaganda videos that enhance this side).

Bloody and long battles have decreed in 2017 the fall of Mosul and Racca representing the end of the Islamic State but certainly not of an ideology and of the followers of ideology. The fighters of Allah could go to other destinations and reorganize carrying within themselves the stigmata for the re-establishment.

\section{Operating modes}

\section{Propaganda}

Propaganda is carried out as a new weapon of war to spread the will of the most extreme Islam. So, we can say that, in addition to the war on the field, this is also a war played on a virtual battlefield.

The Islamic State gives a fundamental importance to communication. The novelty in the Caliphate resides in the fact that the spread operations target both the nation and the citizens. The communication campaign is amplified by production of audio, video, magazines and television, blogs, private and non-private accounts, Facebook, Twitter. All is good to multiply the power of messages. The rebound of all communications finds the web as a major tool, which can reach even young people sensitive to radicalization, beyond their affiliation with al Jihad ${ }^{15}$.

Communication is made to the masses, to small groups (as a process of attraction and fascination) and face to face, in the process of radicalization itself.

The propaganda and target study can determine the counterpropaganda strategy.

\section{Communication to the masses}

The Caliphate has created a cyberwar with a communication strategy that uses online communication to determine a very broad propaganda, as well as to spread reckless deeds amplifying an allure of terrifying advanced of Islamic state. This fame made it possible to conquer entire cities only with fear (already Sun Tsu in "The art of war" said: "The best of the best is not to win a hundred battles over a hundred but to subdue the enemy without fighting"). To

12 www.ilgiornale.it May 18, 2015: "La struttura dell'ISIS chi comanda e gli uomini del potere".

13 www.lettera43.it 19/9/2014: "ISIS. La struttura e la catena di comando dei terroristi islamici".

14 www.lastampa.it: "Il vertice dell'Isis in crisi dopo la morte di Al Adnani”. Sept. 1, 2016. www.ilfoglio.it: “Come funziona l'ISIS? Struttura, organizzazione e controllo del territorio". Nov. 26, 2015. www.gliocchidellaguerra.it: “Così funziona l'esercito dell'Isis". Nov. 4, 2016.

15 Daesh Matrix. Albanese, Gargiulo, Molle, Scigliano, Valdenassi. AGC Communication September 2016. Page 86. 
succeed in this, platforms were set up to spread the jihadist message, so that it could reach every level of population.

The observation as a criminologist is that these types of message always have a winning religious allure in the fascination of the possible adept. The Caliphate grievances are however political, but they use religion as a justification for violence.

In fact, if we look at some of the Al Qaeda messages, which have done school, for example:

- "Muslims are under attack".

- "Only Al Qaeda and its followers are the fighters for the oppressors of Islam".

- "The moment you do not support Al-Qaeda, it means that you support the oppressors".

We realize how religion is a nuclear element in the manipulation of influential masses. So also, ISIS, in the media evolution, uses emotional messages, in the name of religion, with shocking photos and videos, using social media. However, we must note that the claims are very fast (within 24/48 hours for example in the attribution of an act of violence).

But what is the purpose of this mass communication? First, it is a popular communication it needs to make known the "creed" of the Islamic State, it needs to spread the faith, to annul the information deemed false by them, to fascinate and enlist, to coordinate the actions and to give the command of the call action.

However, we must also observe that the messages that are disclosed not only reach the sympathizers or followers, but also reach the enemies, with the express purpose of getting statements and proclamations to them.

There is an ISIS communication office and it is a pillar of the power structure ${ }^{16}$. It shows the daily life, shows the war against the infidels and coordinates the activity between the various forces. There are about 40 production companies, 4 national and 36 regional (2015 data), and songs are also used in the videos. In mass dissemination activities, documents such as press releases, leaflets and even Imam diplomas are also produced. Books and essays have also been published.

Propaganda increases after a terrorist action. What is a production company for? In a video of the house "at the Ghuraba"17 it is explained that the production company serves not only to send messages to the world, but also to collect images, or messages, or audio/conversations from the world, which will then be reworked and sent back to the world. ISIS affiliates have protected accounts. The task of the user who uses the network is to post photos, files, audio that will be re-edited by production companies and re-placed on special channels for communication to supporters. Data of AGC Communication say that the worldwide distribution of a specific post takes place in about 15 days (this was seen by checking the time of a post to return to the person who posted it). The use of production companies serves two levels: the first level, the one already overwritten of propaganda and fascination with the masses, the second level, extremely practical, serves to coordinate the various forces, or to explain how to reach the Islamic State, how to join the group, how to build bombs, how women can join the fighters, how they must behave, the rules for educating their children, what they have to cook for the terrorist. Moreover, since the combatants now do not come only from the Arab-speaking world, but also come from other areas, online Arabic courses have been set up. The jihadist must learn the Quran in Arabic although it is still explained in the language of origin.

\section{Communication towards small groups}

The Islamic State has established its own mosques from which the sermons of their Imams depart ${ }^{18}$. The sermons are all similar and affirm the expansion of the Caliphate in the world. "The organization will have the garrison over Egypt, Morocco, Yemen,
Palestine, conquering the land of the Romans and Franks where they will swear obedience to the Caliph or the population will be killed, establishing the state of the Caliphate with the sword". (23 sit.). And in this scenario, there will be no place for Saudi Arabia.

According to analyst Claude Salhani, there are three reasons why Saudi Arabia would be ISIS' goal:

- A historical motivation: To resume Osama Bin Laden's fight against the Saudi royal family.

- A political motivation: If the Caliphate returns, Saudi Arabia has no reason to exist anymore.

- Economic motivation: The Caliphate needs a State and the taking of Arabia, with its oil wealth, would guarantee the Caliphate further independence. (11 bibl.).

We believe that a description of the subjects of teaching in the school of the Islamic State can be included in the communication to the middle groups ${ }^{19}$.

The teacher has fundamental tasks including teaching Arabic language grammar, never using examples that could contradict the Sharia and the politics of the Islamic State. It must teach the awareness that all the laws of the physics of chemistry are derived from the laws of God's creation. From the laws of God's creation, it derives all and those who disagree must be held liable. Teachers must pass the commitment to Islam because the land of Muslims is the land in which God rules. It is also interesting to observe the abolished teaching materials: music (except for the sacred songs in the Islamic tradition called "nasheed"), nationalist education, social studies, history, art, sport, philosophy, sociology, psychology, religions outside the Radical Islam. It is not allowed to teach mathematics related to finance and economics. Abolition of all the sciences that derive from Darwin, since creation is given only by God Almighty. Furthermore, everything that does not agree with the Islamic Sharia, all Syrian Arab songs, is removed.

We must also emphasize the communication between small groups that takes place on the web. And from the web also the possibilities of teaching are departing. News of December 2017: an Islamic terrorist, Nabir Benamir, is arrested in Genoa, who via telegram exchanged files to teach the construction of devices (as well as propaganda on suicide missions) and instructions on how to turn a mobile phone into a detonator. Interesting that the investigators have found a proclamation announcement to the Islamic State with stamps that establish conditions, services, places to enlist and sanctions for those who break the oath ${ }^{20}$.

Once the subject has been fascinated and has looked for instructions, he can come across a "Training for Jihad" for aspiring martyrs. This creates forums where you can exchange coded messages. And these messages, like messages for the great masses, can be both initiatory and factual. Where the indoctrination has already been done the sleeper cells await orders for martyrdom and this can be done by linking to small groups on the web.

\section{Individual communication, recruitment, radicalization}

When, for a variety of reasons, a person decides to enter the Jihadthemed chats, the attitude can be passive, so just listen, or start being

16 www.securitysummit.it CISINT GAP communication. Workshop Daesh Cyberwarfare. Dottor Antonio Albanese Roma June 10, 2015.

17 www.facebook.com Ghuraba media.

18 waradana.com

19 "Lo Stato Islamico" age communication A. Albanese et al.

20 www.lastampa.it December 19, 2017 “A Genova arrestato terrorista islamico". 
active. From the interrogation of the repentant terrorist Mido it is clear that various discussions took place on a social network (Zello) and on Telegram. This network had been called "State of the Caliphate". Its words show how even in the social network there is a hierarchy. People disguise themselves under pseudonyms. Hierarchical scales serve to direct and control strands. What Mido was dealing with was called the "Dialogue Branch" and he selected users who could participate in the discussions, but whoever came back had to swear an oath to the Ancient Islamic Law. In addition to this there were secret chats now being examined by the investigators ${ }^{21}$.

In virtual recruiting, therefore, a chat is used, where a forum is indexed and the person who manages the forum's thread identifies the subject. Same way people can be identified in prayer meetings.

Among other things, we must differentiate the people who are starting a process of radicalization that come from the Muslim lands and the path that led the Foreign Fighters. For the first group, social, political and psychological reasons are identified (for example, financial hardship or recollection of the ancient political splendors of the Caliphate). For the second group, conversion takes place at the time of departure. Normally they are not people of low economic level, they know well the use of the Internet, they are not motivated by hatred, they are not interested in radical state models ${ }^{22}$.

When an aspiring jihadist approaches the terrorist group, what happens?

In the initial stages recruiters use a psychological technique called "grooming" which is normally also adopted by pedophiles. They listen to problems, try to win trust and in the meantime study the character, habits, bad moods and revindication of recruiting.

Then insert the aspiring fighters into three categories:

\section{- Fall in love with the war}

\section{- Fall in love with Martyrdom}

- Fall in love with Justice (whatever it is)

Obviously depending on the type there will be a different way of radicalization with a different communication method.

For those in love with war, communication is severe with features of grandeur and military film and combat scenes like video games are used.

For the Lovers of Martyrdom, they talk about the great battle that ends at the end of the world.

For those in love with Justice, it is explained to the Jihad as a humanitarian mission to save the children victims of the enemies of ISIS.

In any way the recruiter tries to justify the violence, insinuating the idea that only the chosen ones are worthy to live and try in any way to increase the guilt of recruiting if he does not feel able to manage the action. Use a brain washing replacing prior culture and education with new expectations placed on him. At this point the die is cast. All that is external to Islam is perceived in a persecutory key. However, the passage takes place through symbols: changing the name, for example, or using the niqab or long beard. The language is turned into an "uncritical jumble of slogans".

What happens to the new radicalized?

Before facing the journey, the almost-fighter camouflages his intention. He creates a false profile on Facebook, he secretly prepares documents, adapts himself to the surrounding life, dialogues with his parents, frequents locals, wears conformed clothes. At this point he is ready for the lands of Daesh.

He departs and as soon as he reaches its destination, the favorable terrain allows coercive persuasion techniques:

- he is isolated and is made totally dependent on a charismatic figure

- he is physically weakened with a diet that is quantitatively and qualitatively regulated with a higher intake of carbohydrates, with a reduction in sleep
- he is harassed with a criticism to the usual system of values with their general questioning and condemnation

- he is indoctrinated by proposing new values and new behaviors (with a promise to redeem his condition as soon as he is part of the new system and in this case with emphasis on the models of those who have already completed this radicalization process $)^{23}$.

The aspiring jihadist has a training to do.

The training consists of 7 classes $(32 \text { bibl. })^{24}$ :

- Islamic law and Jihad

- Use of explosives. Basic/advanced class

- Use of small weapons (rifles AK47/M-16, pistols, grenades)

- Assassination techniques (also with toxic and chemical substances)

- Grapple combat

- Physical enhancement

- Targeting, intelligence and communication

The basic classes end in 15 days, the advanced classes have a duration of 45 to 60 days.

After the basic training, there are specializations in:

destruction of buildings with explosives

preparation of bombs using civil material

technical surveillance

topographic maps

installation of bedbugs

search for bugs

development of films and photographs

ability to develop reports

The practice is accompanied by a manual of theory on CDROM (Manual of Jihad in 11 volumes) and in paper version (Military studies about the Jihad Against the Tyrants - 180 pages which explains how to live abroad in secrecy, how to behave in the family, how to behave in front of the enemy).

At the end of the training the behavior of the jihadist aspirant is evaluated and if not appropriate, physical sanctions are applied (for example they are lowered into large containers of water or forced to run barefoot on hot sand or imprisoned in tiny cells until they are suffocated or tortured up to death).

I would also like to draw attention to a path of radicalization on which we could possibly have better control, namely, the path of radicalization that can be carried out in prison. "Radicalization is increasing proportionally to the increase of North African citizens", says Angelo Urso, general secretary of the UIL pa (explaining to panorama.it) and the Penitentiary Police is monitoring this phenomenon ${ }^{25}$.

What are the mechanisms of moral disengagement to attract the aspiring jihadist? Meanwhile, we begin to say that the moral

21 www.larepubblica.it Erica di Blasi: "Mido il terrorista islamico sceglie di collaborare. Arriva anche le FBI per interrogarlo". August 2, 2017.

22 "Nella mente di un jihadista" Corrado De Rosa. Il percorso di radicalizzazione - page 20 .

23 www.cesnur.org "Tra brainwashing e libera scelta. Per una lettura psicologica dell'affiliazione ai nuovi movimenti religiosi." Mario Aletti, Claudia Alberico.

24 V. Mastronardi: "Moral refrain mechanism in the formation of the terrorist and Islamic terrorism". University "La Sapienza", Rome, Faculty of Medicine, Department of psychiatry and psychological medicine, Teaching of forensic psychopathology, Observatory of behaviors and deviance.

25 http://www.panorama.it/ 8 giugno 2017. "Terrorismo il rischio della radicalizzazione in carcere". Nadia Francalacci. 
disengagement is a set of learned internal resources that frees the person from a self-condemnation when he contradicts the innate internal rules ${ }^{26}$. According to Bandura there is an interaction between the person, the behavior and the environment in a mutually dependent way and the internal regulation of the conduct is given by the union of these factors. Again, according to Bandura, there are processes to implement a moral release, that can be distinguished by groups. The first group is given by the disengagement processes related to the definition of Conduct. The second group is given by mechanisms that determine an alteration in the interaction cause-effect. The third group is given by a revaluation of the victim.

Now we will analyze all the phases described by Bandura that are applicable to the moral disengagement that is given to the aspiring jihadist in the path to terrorism (the same application of the phases given by Prof. Mastronardi in the psychiatric explanation and communication of the training suffered by aspiring fighters of Allah).

First group:

- Moral justification: higher purposes are sought to hide the habit (ex: "Let's save the people from the subordination of enemies and the devil"; "We must save the world")

- Euphemistic labeling: to mask the meaning of the action and to reduce the pain of consequences (e.g.: using a particular language such as: finishing off a person instead of killing a person, side effects instead of killing innocent people, necessary surgery; etc. ... etc. ..)

- Advantageous comparison: comparison with worse actions (the only defense weapon we have to end the cruelties inflicted on our population, the attacks made by the fighters of Allah are acts of martyrdom and altruism)

Second group:

- Displacement of responsibility: the responsibility of the action is given to an external figure (we have orders from above; the responsibility lies with whoever commands and decides and in any case our ideology is correct)

- Dissemination of responsibility: to generate a sense of nonresponsibility, the action carried out by a group does not give responsibility to an individual

- Distortion of consequences (the minimization or distortion of perception based on the potential benefits that are obtained) Third group

- Dehumanization (the others are sub-human without judgment or possessed by demons or not sensitive to mistreatment)

- Attribution of guilt (the behavior is only defensive behavior, rarely the antagonists are innocent) (34 bibl).

\section{Action mode}

What distinguishes ISIS in the mode of action such as to be indicative of its work? ${ }^{27}$

An essential characteristic is the use of terror as a weapon towards the enemy. Terror is sown above all by using kamikaze. The most used vector is the car bomb, especially in urban warfare. In this war after the explosions come waves of fighters towards the enemy to hit him. According to Kahvadzhi (analyst for the Middle East) the use of fear is ISIS' most winning weapon. There would be recruiters who choose fighters depending on employment needs. Another weapon is intimidation, using the execution of prisoners, both in front of their colleagues and in a public way, filming them to share later these acts via social or any channel of diffusion/communication.

We frequently repeat that Islamic culture is a liquid culture and therefore the third characteristic that obviously derives from culture is the extreme mobility of the Fighters. They move in small highspeed groups normally on pick-ups. Although during the terror campaigns they steal heavy vehicles to enemies, like tanks, they do not normally use them on the battlefield because they are easily identified by the air force.

For this reason, the intervention of the international coalition is difficult because until now they used airplanes. Moreover, as Fabrice Balansh ${ }^{28}$ observes, the Islamic State is intertwined with the civilian population. This makes it difficult to discern and the attack done against the Islamic state, which also includes civilians, is exploited as a psychological weapon. Another type of action is visibility. The visibility has meant that the fighters in two years have gone from 10,000 to 120,000 and managed to attract the sympathy of foreigners. Al Qaeda had never been able to do this. In addition to modern language they have also used an ancient language, in fact ISIS has contacted the elders by establishing blood bonds by marrying the daughters of the elderly to the Emirs of the Islamic State. Obviously if the covenant is rejected the whole family is killed.

Unlike the contemporary army, the ISIS structure makes no difference between the strategic, operational and tactical levels. For ISIS, success is a fast pace determined by the sum of small military successes. There are both traditional war tactics, mixed with urban warfare, and terrorist tactics. After the latest airstrikes, they have reduced even more the number of teams from 8 to 10 men with two or three vehicles, where the flag of success is their ability to hide. Not only the orders given are short orders, with the incentive to achieve the result, but also, they leave the units on the field free and independent in the use of the tactics best suited to achieve the goal.

How does a typical operation take place? First, it is preceded by psychological operations where via the web the Islamic State spreads messages of demoralization and terror towards the enemies and to the civilians who live in the areas targeted. Subsequently through WhatsApp a mobile unit is established with $8 / 10$ fighters and two or three vehicles. The time to get together is about two or three hours. The coordination time is one and a half hours and then the operation begins.

Meanwhile, we see a consideration: Al Qaeda has waged its war against a distant enemy and avoided being targeted, while ISIS has initially chosen Sunni areas to fight its war. This way of acting gets the support of the population and have initial psychological support and few losses. In any case, the Arsenal available to the Islamic State is impressive and comes from the spoils of war, above all of Iraq and Syria.

The weapons in possession of ISIS are ${ }^{29}$ :

- Tank T 55: Soviet manufacture still in use in other armies. Heavy armor. Evolution and improvement of the T54 realized after the Second World War equipped with a diesel cylinder 38.88 liter 12-cylinder V55 engine. Number of ammunitions for the main armament: 35 . Equipped with a fume extractor on the cannon and abandonment of the mushroom fan that characterized the T54. Very sloping frontal armor and turret with rounded lines to facilitate the rebound of the bullets. It is estimated that the ISIS has around 30.

26 https://www.psicologiaedintorni.it/ blog wordpress.com: "Il disimpegno morale. I meccanismi di disimpegno morale proposti da Bandura".

27 https://www.azattyq.org/ - "Lo Stato Islamico". Agp Communication. A. Albanese et al., page 25.

28 www.gremmo.mom.fr

29 www.businessmonitor.com - Real information www.altervista.org - Le armi adoperate dall'Isis. 
- Tank T 72: Soviet manufacture of second-generation heavy armor. Produced since 1971. Armament equipped with the laser rangefinder THE- K1 and night vision device TPN- 1- 49- 23. Smooth cannon with 44 strokes coaxial machine gun with 2000 shots and additional machine gun with 300 shots.

- Ak-47 or Kalashnikov assault rifle produced since 1949, shooting cadence 600 rounds per minute cyclical, 40 rounds per minute the semi-automatic and 100 rounds per minute automatic.

- M79 Osa rocket launcher: probable manufacture of Croatian anti-tank weapon fires unguided projectiles in direct view and is effective against tanks. It shoots six shots a minute. The best effective distance is $350 \mathrm{~m}$.

- RBG Launchers - 6. Light semi-automatic intended for infantry. Croatian origin

- $\quad$ RPG 7 portable anti-tank weapon used on the shoulder. Soviet and Chinese origin

- Obice M198: medium-sized artillery. US manufacture. It must be towed from one place to another. Built after the Second World War.

- Model 59-1 cannon: Chinese copy of Soviet M46 weapon. It must be towed. It has a cannon with the longest range of action with a maximum shot over $27 \mathrm{~km}$.

- Anti-aircraft gun ZU-23-2: Soviet weapon fires 400 rounds per minute up to $2 \mathrm{~km}$.

- Manual missile launcher FIM - 92 Stinger: infrared missile launcher designed in the United States used shoulder mounted in service in 1981.

- Anti-tank missile HJ-8: Chinese manufacture has a range up to 6000 meters. effective against bunkers and tanks.

- Heavy machine gun DSHK1938 duska: Soviet manufacture dating back to 1938 used by the Soviet Union in World War II is still produced now $(67,68)$.

Ammunition would come from China and the United States ${ }^{30}$.

\section{Suicides and attacks}

We can identify three types of attacks: those defined by the heads of the Islamic State, those of the Lone Rangers and those of groups composed of people without training ${ }^{31}$. In the first group we recognize the most lethal attacks in terms of the number of people killed, such as the Bataclan massacre. The killings organized by the Lone Rangers are normally a small number of people except the Nice massacre. The third group includes attacks with a minimal impact on the number of people since the jihadists without training have less capacity in their intent (in this group, for example, we include attacks in Barcelona and Cambrils).

They affect those who feel they have hit them. The leaders of ISIS have developed a ranking of hatred consisting of 4 steps: the most hated step is given by countries that bombard the jihadist lands i.e. France, England, Belgium, Holland and Denmark; the second step are the states that send the soldiers to face the clinch with the fighters of Allah that is Turkey and Iran; the third step is formed by the countries that send the soldiers to garrison structures of public utility and train the Kurds to the fight like Italy that, however, has never started any guerrilla against the jihadists; on the fourth step the states that do nothing.

We must underline that some types of attacks, which do not fall within this ranking, have been made either by solitary wolves or by autonomous micro cells. For this reason, apparently, they do not seem to be identified in this classification. It goes without saying that if you want to avoid the attack of the leaders of ISIS, foreign policy is the master, while if you want to stem the attacks of the solitary wolves and micro cells the investment must be made on the security forces.

\section{Profiling}

Who is the violent extremist and who could become? What are the psychological characteristics and what are the signs and symptoms of a subject affiliated with al Jihad? Before entering into profiling specifications, I want to report a research where we tried to identify common traits of Allah's fighter to make a summary identikit $^{33}$. The data, although not exhaustive, can give an indication $^{32}$. Two categories have been identified:

- First typology: males between 20 and 30 years old and European normal aspect, level of low middle schooling with ascending united family and inclination towards religious fanaticism. He belongs to the Muslim population under occupied or unemployed tendentially marginalized who turns to the Islamic religion to have an identity. Normally they are children of vulnerable immigrants from socio-religious political-cultural aspects that choose violence as identification. So, we are speaking of the second/third generation of immigrants, even if some jihadist cells come from first generation immigrants with radicalization in the country that welcomed them. To this first type belong the Bataclan terrorists. - Second type: Muslims of good family integrated and with an elevated level of education. Attending highest level schools abroad. Dangerous, able to achieve refined strategies. Skilled at leading a network, able to modulate the organization spread in various territories even distant from each other.

First, it would be too simple and too comforting to think that Islamic terrorists are psychopaths. If they are normally able to understand and want, the few psychopaths that are enrolled (according to Europol, 20\% suffer from psychiatric disorders, but data, if confirmed, are in contrast with scientific studies (56 bibl.)) have normally marginal roles, as discipline, speed and organization need even higher mental structures, far more than other violent criminals. In any case, the psychopath is normally supported by egocentrism and lack of empathy, while the terrorist has close ties with the group of elects with whom he links empathetic relations. We should go deep into the differentiating mechanisms between psychopathic subjects and subjects who are incapable of selfdetermination and evaluate suicide supported by the beliefs of the Quran as altruistic suicide, because it brings benefits to society, or fatalistic because it is due to the prescriptions of Allah. I believe that the correct diagnosis about the behavior of suicide bombers is a depressive, frustrated and redemptive will. Poverty and low level of education are not specific bases for the path towards radicalization. Foreign fighters normally leave a well-off society and bring with them a high degree of education, although the elevated level of education is also typical of the Islamic fighters themselves. Normally young males find answers to common challenges in radical fundamentalism: sense of group and affiliation with anxiety decreasing and control of this with indisputable axioms; recognition of actions and support in terrorist acts with

30 www.agccommunication.eu/component/content/article/89-regoledi ingaggio/8496-ISIS-armi-USA.

31 www.ilfoglio.it "I tre tipi di attentati dell'ISIS che spiegano quanto 1'Italia è in pericolo" Alessandro Orsini, Aug. 29, 2017.

32 www.sicurezzaegiustizia.com "Il fenomeno della radicalizzazione violenta e del proselitismo in carcere. Profiling dell'estremista violento". Augusto Zaccariello, n. III - MMXV.

33 www.lescienze.it "Nella mente del terrorista: strategie di prevenzione". Giovanni Sabato. April 23, 2016. 
confidence in them and flattery; to this are added the dynamics of the groups such as the "polarization" that moves the positions taken towards the most extreme and the "dehumanization" that makes people see beyond the group as worthless ${ }^{33}$. So the jihadist must be included in a group and in a context that has determined the choice of radicalization. This indoctrinating ideology silences crises of conscience and moral constraints using fundamentally the projection, that juts out the responsibilities of that unacceptable part of himself, blaming others and allowing an inherent violence or perverse and dominant narcissism. Not only that, the group allows to stem the most disturbing ideas, as if it is a dissociative element, trying to focus practical aspects and preparation of military nature and, as a mantra, needs to celebrate death and emphasize suicide, as a murder that uses as a weapon the body, with the aim to be sanctified in the glory of the Martyrs and finally reach the Paradise of Allah redeeming in every way the earthly life. The point of view of the Jungian psychoanalyst Luigi Zoja about European terrorists is interesting. He believes that they are the product of the conflict of open voids between opposing cultures both the one of origin and the other of the Occident, tested on an ethical level. In the second or third generation Islamists there is the dissolution of the sex taboo, very rooted in the culture of origin, and the nonculture towards the problem of death about Occidental culture. Freud would say Eros and Thanatos. In addition, there is the dissolution of the figure of the father, recovered from "the hero" of Islam. Moreover, according to Jung, the legacy of culture and of collective unconscious cannot disappear, it can only be removed. Sooner or later it re-emerges, sometimes in a deflagrating way ${ }^{34}$. Incredibly, ISIS offers a purpose in life obtained with death. The purpose in life is the certainties, which he uses as anxiolytic. It puts order in good and bad. It gives purpose overtaking death and the goal is happiness, recognition and personal triumph. It grants a sense of belonging to a group and, in any case, it will make history, managing an identity destabilization and presenting itself strongly, though terrifying, capable of channeling and managing a liquid historical culture like the Islamic one, in search of redemption and groups of Occidental cultural identitarians depleted of a too fast modern society, that has lost the primary reference points. If we make an analysis on the ISIS phenomenon we can deduce that it enters the field of psychological manipulations giving an answer to the dissatisfaction of a society in which they do not recognize themselves, that does not stimulate, where the points of reference have fallen. It exploits the need to belong to a group, to be recognized and rewarded, and also gives vent to irrational impulses such as death. Also, it seeks to destroy the historical past of a civilization, both to deprive the population of historical memory, and to scare at the devastation of the symbols of human evolution ${ }^{35}$.

\section{Subjects dedicated to the action}

Each subject described can be connected either to educate himself or in a manner closer to the "Virtual coaches" or virtual trainers who guide and are present in every step from recruitment to the coordination of a possible attack ${ }^{36}$. It is also interesting to understand what behavior is related to the type of attack, what is the modus operandi, if there is a chosen day of the week, if there is a time of the day and if, somehow, it is linked to religious phases. Since we have seen previously that most of the Fighters of Allah are not psychopaths, but they are people with high intelligence and knowledge at this point their behavior is more easily predictable ${ }^{37}$.

\section{Lone wolves}

This figure bears witness to one of the strongest forms of radicalization. The use of lone wolves for the propaganda of terror goes hand in hand with the confusion created specifically for this figure. The Caliphate advises to act without asking anyone's permission, separating the programmed operations given by the coordinated groups with respect to the autonomous operations of the Lone Wolves who do not obey the central logic. ISIS consents to the action of the lone wolf in exchange for a promise of fidelity and a filiation. The goal is an effortless publicity given by an invaded mythomaniac who protects the organization. The assonance with the figure of the wolf derives from the capacity and effect given by the speed of the action. We have already said how the Arab culture is a liquid culture and the lone wolf fits perfectly in this context. The ideology and/or group of belonging have the function of a pack. The terrorist - wolf acts on his own, in the ways that he decides and infuses an atavistic and perhaps unique terror. Normally he is a subject that is estranged from the society, that he hates, and he has as its essential component the redemption of himself. It fits well in this historical context where anyone is afraid of anyone. Even because in the process of globalization, the fear of what is extraneous or foreign clashes with the guilt of non-acceptance, so a sort of alteration pre-alarm/fear/defense/escape/shame is created. The virtual world of this society, which has no boundaries limited by geography, instills even more this feeling of powerlessness towards what is outside. Normally it has no affiliations to groups and the characteristic that determines the difficulty of identifying it is invisibility: age $20-30$ years, common appearance. Normally they are men with high intellectual abilities that can understand what they want. The psychological traits are always of quarrelsome, irascible and aggressive people. Preferred target: civilian population. The preferred weapons are firearms, devices and armed hijackings ${ }^{38}$. Even the explosive belt is a weapon of the solitary wolf as it is perfectly camouflaged. Many of them come from the criminal world so crime is intertwined with extremism and the religious or political cause hides an illicit behavior. The author of the massacre in Nice was a Lone Rangers and after this bloody massacre ISIS immediately confirmed and claimed the attack. It then launched a Lone Rangers training course on Telegram. The lessons are divided into:

- military and logistical bases for conducting Jihad in the Occident

- personal safety

- metropolitan military tactics

explosions science

avoidance of intelligence services ${ }^{39}$.

\section{Coordinated groups}

The evolution of the Lone Ranger leads to aggregation in perfectly coordinated groups by a central command and each selfsufficient. The central command imparts orders and actions and dispenses culture in the field. We can talk then of a criminal herd and the evolution took place to improve the technicality, coordinate

\footnotetext{
34 www.huffingtonpost.it "Nella mente di un terrorista". Antonella Tarpino. October 4, 2017.

35 Il Corriere della Sera. Ebook 2016 "Nella mente di un jihadista. Per una psicologia dell'ISIS". Corrado de Rosa.

36 www.ilpost.it "Non chiamiamoli lupi solitari". April 3, 2017.

37 www.lookoutnews.it/ "Terrorismo. È possibile prevedere gli attentati?" May 13, 2017.

38 urbeetius.org > uploads $>$ "Il lupo solitario: terrorismo ideologico e religioso nella società liquida”. Monique Iandolo, Vincenzo Mastronardi, November 2017.

39 Il Corriere della Sera. Ebook 2016 "Nella mente di un jihadista. Per una psicologia dell'ISIS'. Corrado de Rosa.
} 
the attacks, consequently make the world show death, creating more and more anxiety and fear in the population more and more forcing the modification of social behavior ${ }^{40}$.

\section{Foreign fighters}

They are people who do not belong to the countries where the Caliphate was born, but they decide to affiliate and embrace their ideologies ${ }^{41}$. The profile of the Foreign Fighter is very varied. He may come from the poorest society or from wealthy families. The level of education can be very different. Enlistment takes place both between Muslim families who already live in a different country and between people who convert. They leave their country to the Middle East where they do training and usually return by striking the world they come from. Although the profile is varied, most Foreign Fighters are young people of good cultural level, with an excellent culture in the use of the Internet, not interested in the model proposed by Islam, not interested in looking for wives or concubines and usually do not integrate with Islamic society. Sometimes they come from the outskirts of the Occidental cities, where they do not feel integrated neither from the intellectual point of view nor from the social point of view and live with a sense of dissatisfaction due to the lack of recognition of themselves by the society around them and consequently frustration towards the life they lead. It is sure that these characteristics of life can more easily be a fertile ground for inclusion and adherence to any kind of fundamentalism. How can these people go from being well off to a Western world to suicide in a world of radicalism? Part of this is also due to the use of a certain drug called Captagon. Captagon is phenethylline. Link between amphetamine and theophylline for both of which acts as a prodrug. The trade names are Captagon, Biocapton and Fitton. The properties are of anesthesia from pain, suppression of hunger, loss of any inhibition. Euphorizing, it was also used by the Bataclan terrorists. For this reason, it is called the ISIS drug or the Jihad drug. The terrorists make extensive use of it, especially by giving it to the bombers and unfortunately also to the children, as was seen in the kamikaze children of Boko Haram Nigeria, drugged before becoming Belt Bomb Children. The cost is about $€ 5$ per tablet and ISIS, in addition to be a user, controls the deal in all areas ${ }^{42}$.

\section{The role of women}

What motivates a woman to embrace the Islamic cause? As for men they have an inner emptiness, they get a definition of role, they follow an ideological and religious belief, they define a social status, they have the prospect of marriage with a hero with whom they will have future heroes and incredibly do not feel used. Women who are dedicated to the jihadist cause not only support it with propaganda and education to their children to become militants of Isis, but in some areas, they are ready to fight. Within the caliphate there is no real organization of women in war, but there are still precedents in Al Qaeda. The woman must follow strict rules in the Caliphate. They are veiled, hidden, locked up in the house and forced to marry even at the age of 9. Despite being the mother of the Fighters the modern woman could give problems. Therefore, the female Foreign Fighters who want to fight for the Jihad do not become soldiers of the Islamic State, but wives of the fighters (and therefore mothers of jihadists). To find wives for fighters even marriage agencies were created with honeymooners in the Islamic state. The fighters had also posed the question of whether it was permissible to kill a woman. Theologians have decreed that it is permitted. The Caliphate still uses women in the intelligence service ${ }^{43}$. But not only. ISIS has created a special female police department "AlKhansa" (name of a poet dear to Muhammad), who controls and punishes anyone who does not follow the Sharia. This police department was founded in the Syrian capital Raqqa of the Islamic State. Over 100,000 women live here, both war booty and brought to the brothels of the city, and who have come from the Occident to become wives of jihadists. These women cannot appear in public, they must wear only black veils, gloves to hide their hands, 3 veils to protect their face, and always be accompanied by a male relative. If they do not observe these rules they are buried alive in the sand. Al-Khansa ensures that women do not sit on balconies, do not use perfumes, do not raise their voices and do not expose themselves in any way to light, not even their eyes. Penalty for this or flogging or being bitten (and particularly gruesome even with iron teeth commissioned to rare remaining dental technicians) ${ }^{44}$. Another task of this Gestapo is the control of brothels where ISIS slaves are sold as a reward to the militia returning from the front. If they try to escape and are captured, they are forced to suffer violence from over 100 men. Terror policemen as a salary receive up to $\$ 100 \mathrm{a} \mathrm{month}^{45}$. What is the manual of the jihadist woman? Taken from a jihadist forum in the Arab language of the Quassam Brigade, translated into English by Charlie Winter Quilliam Foundation researcher, translated into Italian and re-launched by the Next Quotidiano: "Women must live in rooms with closed doors and leave the house only in exceptional circumstances. It is always preferable for a woman to remain hidden from the veil and hide herself from society through the veil". Shops of clothes and beauty salons are the work of the devil.

From 7 to 9 years teaching for girls is the Quran and natural sciences.

From 10 to 12 -year-old girls must study what the Quran says about marriage and divorce and they have to learn how to weave, sew and cook.

From 13 to 15 years old they must learn to educate their children, study Islamic history, the life of Muhammad and his followers and Sharia.

In this forum it is considered lawful for a girl/woman to marry from the age of 9 and in any case must be married within the age of 17 (young people within 20 years). Prohibited plastic surgery, piercing and earrings ${ }^{46}$.

And what happens to unfaithful or non-Muslim women who are part of the war booty?

Normally they are sold as sexual slaves that increase the number in brothels; and have a price list: a woman with blue eyes costs more, but if she has no teeth she can also be killed. 50,000 dinars i.e. $€ 35$ for women from 40 to 50 years, 75,000 dinars $€ 52$ for those between 30 and 40, $€ 70$ for girls between 20 and 30 years, $€ 103$ for girls between 10 and 20 years and $€ 140$ for girls from 1 to 9 years. The girls are first raped by the commander and then left to the military and raped several times a day. All this would be possible in the name of Sharia, because to enslave the kuffar (infidel) and

40 www.ilgiornale.it "L'evoluzione del terrorismo islamico: dai lupi solitari al branco". Sergio Iacch, January 26, 2016.

41 www.sapere.it "Chi sono i Foreign Fighters".

42 www.corriere.it "Che cos'è e dove viene prodotto il Captagon, la droga dell'ISIS”. Marta Serafini, May 8, 2017.

43 Ara news.org

44 Blastingnews.com. "ISIS Ecco perché e come punisce la polizia femminile del califfato". Umberto De Palma, December 29, 2015.

45 www.today.it "La polizia femminile dell'ISIS che tortura e opprime le donne in Siria". July 13, 2015.

46 m. huffingtonpost.it "ISIS: Call center, pulizia morale, bordelli per jihadisti: essere donna nel califfato islamico". Umberto de Giovannangeli, June 20, 2015. 
their families, using the wives as concubines would be the "law" according to the online magazine Dabiq ${ }^{47}$.

\section{Belt bomb children}

The use of children in suicide attacks is one of the methods used by ISIS ${ }^{48}$. Shocking use of girls from the apparent age of 1015 years in attacks organized by the Boko Haram group in Nigeria, as well as in Afghanistan and Pakistan. We have news of a fundamental role of indoctrination of children in Pakistan in schools called "Madrassas", present in the north-east of the country, which are Islamic schools under the control of the Taliban. The children used are mainly Iraqi or Syrian children (but also the sons of Foreign Fighters) abandoned by families who are too poor or orphans. Without any schooling, without affection, drug addicts and alcoholics. And not only. Some families sell their children to the Taliban and they then sell these creatures to other groups. Their cost varies between 6,000 and 12,000 dollars. When these children are indoctrinated, they are brainwashed to convince them that during their explosion they will not die because God will protect them. So much so that they are given an amulet or a pendant telling them that it will protect them from death. The child is aware of what he is going to do with the awareness of a child and the horrible and criminal exploitation of brainwashing. Indoctrination of children takes place in about 40 days and the child is trained to become an "Inghimasi". "Inghimasi" means an individual who is able to use light weapons, explosives, explosive belts and ready to kill ${ }^{49}$. Lately the age of the children used has dropped to 6-7 years. Thanks to the work of Noman Benotman and Nikita Malik it was possible to draw a portrait of the life of the children in the Caliphate. The school is aimed at indoctrinating and modifying children in soldiers, so much so that they teach mathematics by adding the bullets. At school they study and memorize the Qur'an, Tawhid (monotheism), Fiqh (jurisprudence), Salat (prayer), Aqeeda (creed), Hadith and Sura (life of Muhammad). Physical education is called Jihad education and includes use of firearms, fighting and swimming. In addition, instructions for maintenance, cleaning and storage of light firearms must be studied. There are operational training camps where children between 10 and 15 years participate. Indoctrination reaches the point where violence is perceived as a normal trait in the child's daily life. Their use will then be aimed at turning them into spies, soldiers, bombers and, moreover, the Caliphate believes that these kids are the best fighters because they were born with an ideology and not converted ${ }^{50}$. The school, whatever it is, which normally prepares for life, provides death as an idea of life. But why use children? Children were called smart bombs (Smarter Bomb - Anat Berk 2012) for the ease in evading the controls. In addition to committing suicide, children are also used to kill and to appear in propaganda to generate ever greater sense of terror in the population.

\section{Personal profiling}

Abu Bakr al-Baghdadi. Profile issued by Iraqi Ministry of the Interior $^{51}$. Ibrahim Awwad Ibrahim Ali al-Badri al-Samarrai. This is the real name of the Cape of ISIS. Originally from Samarra. Born in 1971 in Fallujah, he was the Imam of a mosque in Diyala for years. He earned a doctorate in Islamic studies at the Islamic University of Baghdad. Teacher of Sharia and subsequently Salafist preacher. It is part of the Bou Abbas clan, which claims to be a descendant of Imam Ali Assan Bin Ali, a fundamental requirement to become Caliph ${ }^{52}$. He created an armed group in the province of Diyala. He assumed the leadership of Al Qaeda (which in Iraq is ISIS) after the killing of his former leader Abu Omar al-Baghdadi. His predecessors were killed because the movements were detected. Baghdadi limits movements, contacts and speaks only to people who know him directly. It is surrounded only by the eight councilors of the Shura to which 5 people can be added on special occasions.

\section{Profile of the fighter and the kamikaze}

Both between the ages of 20 and 30. Many Europeans as second-generation exponents or third generation of migratory phenomena. The organizer of the attacks is normally older with a role more resembling the Combatant and more ideological, and his weapons are not real weapons, but it is people used as weapons. The organizer profoundly knows warfare techniques, as the fighter knows them, and is animated by a feeling of revenge for a population. He defines himself as a martyr and believes he is immortal and perennial. The characteristics are cunning, intelligence, calm, the ability to resist imprisonment, ability to overcome the trauma due to killings and massacres. We must also highlight that part of the fighters are mercenaries from Tunisia, Chad, Sudan, Mauritania, Serbia. These willing mercenaries would earn about $€ 10,000$ a month $^{53}$. We intend for mercenaries who are recruited to fight in an armed conflict, which takes a direct part in the war driven by the desire to have a profit previously promised, who is not a member of the Armed Forces of the conflicting parties, motivated by material indemnity and his function serves to undermine the order of a state ${ }^{54}$.

Profile of the subject that can be radicalized (from "Personality and psychopathology" G. Palermo - V. M. Mastronardi) ${ }^{55}$.

The radicalizable subject has some peculiarities among which are detectable:

- Psychological fragility

- Degree of radicalization

- Psychological rigidity

- Sadism and control of impulses and lack of empathy

Social claim for wrongs suffered

Low stress tolerance threshold

Depression

- Malignant narcissism

- Penalizing losses

- Identity research, even if negative (the superman complex)

- Search for subversive group support (pseudo securities)

- Predisposition to violence with consequent lessons of do-ityourself terrorism and the aid of web and forums, with consequent utopian vision of the world (16). We need to know how to evaluate the basic characteristics of the individual personality (schizoid/paranoid, narcissistic, antisocial,

47 www.huffingtonpost.it "ISIS dà della prostituta a Michelle Obama. Ma la condizione della donna nello Stato islamico è agghiacciante". Umberto de Giovannangeli, May 24, 2015.

48 www. Cerchioblu.org Antonella Marchesella "Belt Bomb children l'uso di bambini come bombe umane." January 12, 2015.

49 www.ilpost.it "Cosa fare dei bambini addestrati dall'ISIS". June 23, 2017.

50 m.huffingtonpost.it "I bambini di Daesh". September 1, 2016.

51 www.agccommunication.eu: "Profilo di Abu Bakr al-Baghdadi".

52 Huffingtonpost.it "Wikileaks dell'ISIS. I segreti del califfato svelati da un alto dirigente dello Stato islamico". Daniele Mastrogiacomo, November 26, 2014.

53 Wordpress.com - Risveglio nazionale. "Che cos'è l'ISIS e chi sono i suoi mercenari pagati anche $€ 10000$ ”. February 21, 2015.

54 www.analisidifesa.it "Mercenari contractors Foreign Fighters protagonisti degli odierni conflitti”. Pietro Orizio, August 24, 2015.

55 From "Personalità e Psicopatologie" G. Palermo -V. Mastronardi ne "Il profilo criminologico, dalla scena del crimine ai profili socio psicologici”. Giuffrè Editore 2005. 
histrionic, dependent, obsessive-compulsive etc. in PalermoMastronardi 2005) also remembering any psychopathologies (CFR DSM5 and ICD-10).

\section{Recruiter profile}

Recruiters can adapt their ideology according to the psychological profile of the person in front of them.

The Islamic State has an anxiogenic emotional approach, pushing the person towards a paranoid behavior. This was written by Dounia Bouzar, a French anthropologist who founded the center for the prevention of sectarian drift linked to Islam ${ }^{56}$. Specialist in the relationship between man, religion and the management of secularism, he leads anti-radicalization battles in favor of the boys. The recruiters suggest to the recruited a reason to enlist and this reason corresponds to an ideal of the boys hidden in the unconscious. They speak of worlds of brotherhood and solidarity and only when the boys arrive in the land of Daesh discover the truth and if they try to go back they are killed. They never speak of the world of violence surrounding this faction of extremists. To convince the racializable subject they talk about a world governed by gray eminences (which play on power and science) and that the entire population either lives in a sort of limbo in such a way that it does not understand or lives corrupt. To overcome corruption, the solution is to escape, the rejection of society or the killing of society, and the strength to overcome this lies in true Islam, that is not what goes back centuries ago, but that of Al Baghdadi. At first, the person who starts a process of radicalization, distrusts the people around him, as family and friends. The recruiter proposes himself as a friend, seducer, professor. He listens to the future prey, motivates him, talks constantly with the identified subject, sometimes they meet each other, but, above all, they exchange thoughts using the Internet and then he introduces him into virtual forums. Thus, the relational recruitment begins, it is the first step towards an ideological recruitment. In this case the person who still feels in symbiosis with a group will eventually adhere to the same ideology. Moreover, they manage to instill the conviction that the news of journalists and newscasts is all manipulated and the only truth is the truth of the propaganda of Daesh.

\section{Profile of the recruiter in prison}

The recruiters are charismatic figures of mild and very fascinating impact and catalysts of prisoners on whom they first start a conversion and then radicalization ${ }^{57}$. They talk about Muhammad and Jihad. In Italy, 33 recruiters were identified: 11 Tunisians, 7 Moroccans, and 7 Egyptians. The others are from Algeria, Gambia, Pakistan, Tanzania, Albania, but also France and Italy. The French man is the 27-years-old son of North Africans; the Italian is a 25-year-old son of North Africans. The recruiters wear Occidental-style clothes, they have an impeccable prison behavior, constantly maintain a low profile, trying not to emerge and participate profitably in the activities. They have an elevated level of culture and Italian language and are usually used as interpreters with new prisoners. The largest number of recruiters in Italy is in Tuscan prisons. Immediately afterwards in Sicilian prisons, while the only Italian is in Piedmont. The recruiter does not necessarily propose radicalization to anyone, because he can also understand which is the best radicalizable subject, but at the same time he also plans drug trafficking or other types of crimes or trafficking of arms as he is not only a reference point and aggregation but also a business reference point just like a Godfather. The only variant, which is negative for us, is that, normally, all the communications take place in Arabic. At this point we can also think that this figure could be a bridge between the Islamic world and organized crime.

\section{Socio-cultural profiling}

To start doing a profiling job, it is more necessary to enter the logic and set-up of another culture. Meanwhile, Arab is not necessarily Muslim, and Muslim is not Arab. The historical roots of pre-Islamic Arab culture (the pre-Islamic era in Arabic is defined as "al jahilittah", i.e. the age of ignorance) leads to a tribal culture where Arab is a poet, generous, knight, he defends needy people and he does it in honor of the tribe. They had the culture of a multitude of women or concubines and the culture of the inferiority of women, so much so that there was the custom of burying alive the first female born as it was dishonorable. The presence of a multitude of concubines went hand in hand with the amount of time they had during the life they led, and they also used their time with rhetoric, that is, the art of narration and the poetry of their deeds, in defending their own tribe and identity. They were shepherds, traders, they produced a wine made from dates and the various Arab tribes were in conflict. The weak point of this corporate structure was the fear of death. And the fear of death disappears with Islam, in fact, in the Qur'an we talk about the "effort" towards the way of God and the effort is "al Jihad". Death is an honorable death, as one does not die, but one lives. One lives in a sort of parallel reality where people who died like you can see you, while those who are on earth or who did not die in this condition do not see you. In the Surah "AL OMRAN" verse 169 it is said: "not to consider dead those who were killed on the path of Allah they are alive and well provided by their Lord", verse 170 "pleased with what Allah for his Grace grants". The narration also makes the history of the eternal tribe. The term SHAHADAH (martyr) is also important. The one who dies as a martyr will have the chance to save 70 family members from hell. Al Jihad is a Sunni characteristic, it is not in the Shiites. The Shiites do not do Jihad because they are waiting for the twelfth apostle and after the advent of the MAHADI they will do Al Jihad. But this MAHADI or 12th apostle will never come and therefore will never do to Jihad. The Sunnis instead do the Jihad. In some Sunni verses, however, we speak of Mahadi. This is because it is said to be an attempt by the Jews to stop the Jihad by introducing these notions through HADID that is human language. But at the same time some Shiites believe that the Mahadi arrives at the time when the Sunnis are killed as much as possible and here is a motivation for other violent acts. Arabic is a language that leads to multiple interpretations due to lack of punctuation. In fact, for example, if you read: "Islam is the only religion saying that God takes you to the right path and no one can take you away from it. Only God leads to the right path those who want to". Is this "only who want" a way to say "those that God wants to lead to the right path" or "People who want to go to the right path??? And from this example various interpretations arise. The surah Al Imran number 110 states: "You are the best community that has ever arisen among men, you believe in Allah, good habits are recommended and what is reprehensible is forbidden". The Prophet says that whoever sees an incorrect malignant act must change it with his hands, if he fails with the language and if he fails with the heart. Therefore, the Islamic religion is based on combating wrongdoing. (here is the perplexity of the incorrect referred to who and what). But what is described of the Muslim Paradise? Everything that is forbidden in life is deprived of any negative meaning. Among other things in the

56 www.redattoresociale.it: "Giovani nella morsa jihadista. Così si convincono di essere eletti da Dio" May 25, 2016.

57 www.panorama.it: "Chi sono i reclutatori islamici nelle carceri italiane" di Nadia Francalacci Jan 10, 2017. 
interpretation of the Arabic language I see a kind of permission on a delicate passage, in fact in 19 Sahn we say the purpose of Paradise: "will wander among them, children of eternal youth, seeing them it will be like seeing scattered pearls ". In Surah Sad verse 49-58: "This is a warning. In truth, the fearful ones will have a pleasant stay. The doors of the gardens of Eden will be open to them. There, comfortably leaned, they will ask for plenty of fruit and drinks. And to those of the same age and with a chaste look, doors will be close. This is what was promised on the day of the report. Truly these are the goods that we grant you and you will never run out of. So, it will be. Instead, the rebels will have the worst of stays: the hell in which they will fall; what a sad bed. So, it will be. And then they will taste boiling water, fetid water and other similar torments".

\section{Geographic profiling}

At this time, the changeability of the conditions makes us take a picture, where the defeat of ISIS in Syria and in Iraq let us reflect on where the jihadists could go. Migration is supposed to have started already since September - October 2017, leaving the areas of Raqqa and Deir ez Zor. All this supported or hindered between Washington and Moscow. But regardless of these areas, flows towards Libya, Tunisia and Somalia have been reported for some time in a section that reaches Niger. The danger is that these countries have weak governments, poor controls and geographical conditions that facilitate penetration. In Afghanistan the penetration is getting stronger so much so that on $27^{\text {th }}$ December 2017 there were a series of attacks in Kabul with the death of 40 people (attack claimed by ISIS). Other destinations are Kazakhstan, Tajikistan, Uzbekistan, Turkmenistan and Kyrgyzstan where infiltration could destabilize these nations but also use the position as an expansion to Russia. Other areas at risk may be Bosnia and Kosovo due to the high level of radicalization and as a point of arrival for Foreign Fighters. Italy is at risk due to its geographical position because it is set on both the Libyan Tunisian and the Balkan routes. Infiltration of jihadists on boats or even overland has already been proven. Italy in 2018 will participate in counter-terrorism operations by sending 500 men against the traffickers of men in Niger ${ }^{58}$. The geographical area in which ISIS was territorialized was between Syria and Iraq and from there it was presented as a state. The settlement took place in territories devastated by wars with lack of food and lack of care. In these territories there were no infrastructures and from the social point of view there were very high rates of unemployment and illiteracy. And certainly, although it is a moving state, it will be the same state model that appears. In "de-structured structures" a stable state, as proposed by terrorist propaganda, is a dream. Moreover, in the laws of ISIS the program is to distribute income to the poor. The Caliphate has set up the streets and built schools in the conquered States. It offered homes with low rents and vaccinations, so marrying the Islamic cause would guarantee a better quality of life. However, life is relegated to a primitive condition with harsh laws, to the point that cities and territories are surrounded by checkpoints to stop any leaks. But what could be the map of countries at risk of terrorism? ${ }^{59}$ The map was presented by Aon. The countries most at risk of attack are Africa, Turkey, United States, United Kingdom, Northern Ireland and Vatican State. Looking at Italy, we see that the north and the center of the country are characterized by minimal risk, while the south is characterized by medium risk. On December 27, 1985, a Palestinian terrorist group Abu Nidal killed 23 people in the massacre at Fiumicino airport. Considering the targets of the energy sector, Nigeria and Colombia are most at risk. Let's now consider Italy and look at where radicalists could settle. Meanwhile, let's start explaining what the Qatar Charity Foundation ${ }^{60}$ is. This foundation depends on the state of Qatar which, with its wealth derived from oil, holds the airline Qatar Airways, the Al Jazeera television network and invests a lot in the sector of sports, for example it is the main sponsor of Barcelona. The Qatar Charity Foundation is an institution of Islamic assistance with the goal of building mosques around the world. In Italy it has started to build 4 mosques in Sicily making 2.5 million euros available. And again, in Italy funding to Islamic communities is, in the majority, supported and financed by non-governmental organizations in Qatar. Saudi Arabia, Egypt, Bahrain, the United Arab Emirates and Yemen have closed their relations with Qatar on charges of financing Islamic terrorism by getting funds to organizations close to Al-Qaeda, Islamic State and Muslim Brotherhood. From the screens of Al Jazeera the leader of Muslim brotherhood Yusuf al Qaradawi says: "If God wants us we will conquer Rome. Not with the sword but with the Dawa"(proselytism). Imam Izzedin Elzir, president of the Union of Islamic Communities of Italy, asserts that 25 million from the NGO Qatar Charity served to build 43 mosques. In a report by the US Department of Justice, it is stated that the money allocated by Qatar Charity to the operations of Al Qaeda is registered by the organization as expenses for building mosques and schools, not for helping the poor.

\section{Language profiling}

The language used by the fighters of Allah is seductive and symbolic. Also, the name of the ISIS propaganda magazine "Dabiq" uses the same name of a small Syrian village battle theater in 1516 . Here the Ottomans defeated the Mamluks who ruled Egypt by imposing Turkish supremacy and the proclamation of the Ottoman Caliphate. Therefore, the fascination and reverberation of this name is understood as a natural continuation of the ancient historical Caliphate. This paper is translated into English, French, German, and Arabic and the images are superior to words in full line with effective modern communication on the masses. Now there is another newspaper the "Rumiyah" that succeeded the Dabiq whose last number was published on July $31^{\text {st }}, 2016$. The first issue of Rumiyah is dated September 5, 2016, the latest to our knowledge September 9, 2017. For some strange reason it always occurs in September. Social communication also uses evocative phrases and many images. The use of language: sentences are written in a simple way, to be understood by everyone, and incisive. In the field of profiling, particular attention must be paid to certain phrases, since the Quran has been revisited and corrected to give religious support to homicides and attacks. Moreover, the use of many terms could be decisive for creating a reliable prediction model ${ }^{61}$. Language is an instrument that reflects a reality and is an instrument of legitimization and de-legitimization of many acts, especially in this case, where actions contrary to human morality are deconstructed for the pursuit of a divine superior end. We can see in the speeches of Islamic fighters how the verbal imperative is a means of propaganda, like the certainty of actions, of the future and of the consequences that above all a dogma of faith can deliver. The repetition of pronouns is important for delimiting the various areas of competence and action. For example:

\footnotetext{
58 www.gliocchidellaguerra.it "La manodopera jihadista e il suo utilizzo in altre aree”. Giovanni Giacalone, January 6, 2018.

59 www.tpi.it "Ma qual è la mappa dei paesi a rischio terrorismo 2017?’. June 20, 2017.

60 www.ilgiornale.it "Così il Qatar finanzia in Italia moschee e scuole coraniche". Sergio Rame, June 5, 2017.

61 www.ilgiornale.it "La strategia linguistica dell'ISIS le parole che attivano i martiri”. Franco Iacch, March 31, 2017.
} 
- "Our world is under threat"

- "It is mandatory to defend the world from contamination"

- "The threat has reached a critical point"

- "Violence is the only way to go"

- "These actions are in accord with Islam"

"The fighters will receive a heavenly reward for doing this"

We must also note that the type of language is found without various interpretations by reading the Quran ${ }^{62}$. In the passages where there is an exhortation to Jihad, I read:

Sura 2 (190-193): "Fight those who fight you for the cause of Allah, kill them wherever you meet them, drive them away. Fight them until the cult is made only to Allah". As in Sura 47: 4 it is said: "When you meet the infidels, kill them with great bloodshed and tighten the chains of the prisoners".

In the rewards of those who believe firmly we see in Sura 3 "the highest of the Paradises" with sensual life, lush oases, exquisite food and many alcoholic drinks. Safe 4 verse n. 89 it is written: "Do not choose friends among the unbelievers until they emigrate for the cause of Allah. If they turn away, then grab them and kill them wherever you find them". Remaining on the Quran we see how many verses invite violence and are unenforceable in a civil human morality. If we read the Quran, we could advance hypotheses about the future. Just as we could have predicted the follies of Hitler that had been written previously on Mein Kampf. And also, one of the latest messages sent by ISIS with great media impact was "We are at your home". And this message is a typical form of narrative that arouses terror for the invasion of privacy and decrees the continuous virtual war that does not break down, although Islamic strongholds continue to fall. Moreover, the imperative "We" put in this sentence, also accentuates the group's cohesion and the infiltration inside the intimate of the spectator. Furthermore, the messages are directed both to the infidels, who must react in a frightened and disordered way, and to the faithful ones who must feel supported and encouraged to feed the rows of the Fighters. Allah Akbar or the questions that have been used to choose who to torture or who to kill are a pretext that highlights this splitting made by language. And language is also part of the show. Just as the faithful feel reinforced in the knowledge of having a saber in their hands, so in the same way and at the same time the enemies must feel the object of the same blade. As for the communication between terrorists, they tend not to be discovered and to carry out screening operations. In fact, they also use handwritten messages, meeting in person and exchanging cell phones to confuse their location and the police in interceptions.

\section{Appointment of criminology in the prevention of Islamist terrorism}

Given that we are talking about prevention of radicalization, processed according to our intervention, depending on the individual historical moment in the personal journey of radicalization, those measures are involved:

\section{- before the radicalization process starts (primary prevention),}

- after a process of radicalization has already begun (secondary prevention)

- third category (tertiary prevention) aimed at those subjects towards whom only the abandonment of violent ideology can proceed, or at least disengagement (that is, abandonment of active militancy without a corresponding abandonment of ideology) and bearing in mind the following classification (from V. Mastronardi's "Manual for criminological operators and forensic psychopathologists", Giuffrè Editore 2012):

- Very demanding subjects in the prevention activity (tending to irrecoverability)

- Recoverable subjects thanks to an individualized and qualified treatment

- Subjects with a positive prognosis of good recovery

Based on the moment of the path to be taken towards radicalization, we can implement a PREVENTIVE INTERVENTION at various levels (LEVEL 1, LEVEL 2, LEVEL 3).

We can use prevention by analyzing the amount of people to reach and work on.

Using a summary but no less eloquent categorization, one can imagine different areas of action:

A 'WIDER AREA (macro-level): to reach a very large number of people through counternarrative or alternative narrative, to get an anti-jihadist message (as already studied in the strategies of social communication). Here the goal is to diminish the appeal and therefore the seduction of the jihadist movement on subjects that could be particularly fragile and receptive to recruitment for individual, family and social problems that we have already seen in previous chapters. Some techniques can be ${ }^{63}$ :

1) To disseminate favorable images of one's own strength

2) Expanding the effects of military operations on the enemy

3) Conditioning the psychological attitudes and political evaluations of the enemy

4) To circumvent censorship, illiteracy, communications interrupted by the enemy

5) To exploit ethnic, cultural, religious and economic differences

6) Provide space for so-called "unconventional" types of war (mass media)

7) To assist with humanitarian peacekeeping operations (93 bibl.). A MEDIA AREA (meso-level): exactly measures to propose positive social ideals with the small community groups reached directly. An example of positive interventions is in schools, particularly, where children considered vulnerable are included.

A RESTRICTED AREA (micro level): here we talk about a One-to-One relationship with staff trained to use individual communication strategies towards:

1) subjects with strong resistance to recovery;

2) with a positive prognosis for recovery;

3) recoverable with various techniques such as counternarrative, or thanks to measures aimed at reinforcing self-esteem or if necessary drug therapies in the case of psychopathologies, drugrelated problems or social reintegration with neighborhood control (Neighborhood Watch).

The Italian approach focuses on the validity of multidisciplinarity and all services from law enforcement to different sectors of society. Professor Mastronardi teaches the extreme importance of considering, at any time, the human conditions that have led the individual to a path towards radicalization. We must always remember the existential and emotional fragilities, the presence of any injuries suffered both in the single life itself and in the marginalization of a surrounding society, penalizing bereavements and situations of strong discomfort that may have pervaded the life of a person and, remember, never to use an attitude ready to criminalize, but to propose as possible

62 www.iltempo.it: "L'odio nel Corano: combattete chi non crede in Allah" November 21, 2015.

63 "Psyops: le operazioni psicologiche nei conflitti asimmetrici" Marco Cannavicci. Giornale di Medicina Militare 2005; 155(4); 513-9. 
the recovery of the latent potential of the individual who could never emerge. To have this positive human approach to a subject to be recovered, we cannot forget the classification of Ponti and Fontanesi which, from 1969 to 1975, used to recover prisoners. In our case we will talk about a new classification targeted and reinterpreted by Prof. Mastronardi.

Very demanding subjects in prevention activity both primary and secondary and tertiary for rooted convictions in terms of "political-religious fanaticism";

Recoverable subjects thanks to an individualized and qualified treatment, with various aids such as for example

- the counternarrative

- NLP (Neurolinguistic programming)

- operational safeguards aimed at personal self-esteem

- drug therapy where there is a pathology frankly diagnosed (e.g. Psychopathologies, addictions)

- policies of social reintegration, also through neighborhood control, the Neighborhood Watch ${ }^{64}$ according to established situational criminology techniques

\section{Subjects with a positive prognosis of good recovery}

The personality and psychopathology tests that could be adopted in this project could be:

- Brief Psychiatric Rating Scale (BPRS)

- Mini International Neuropsychiatric Interview (MINI)

- Neuropsychiatric Inventory (NPI)

- The scale for rapid dimensional assessment (SVARAD)

- Brooks and McKinlay 1983 personality tests

The Adjective checklist to be used both in some more lucky cases by self-administration, and in less lucky cases with the compilation of individual evaluative items by the individual operator/evaluator.

\section{Conclusions}

To go into such an intricate and delicate problem, any kind of force can be important and fundamental in restoring the balance of peace and serenity. Islamic culture is a culture very far from the Occident and requires in-depth studies to understand it and to ensure that in its most extreme meaning it does not harm fundamental human rights.

In these multidisciplinary approaches one could find the way to contain, or better, the solution in the dream of a world of peace and coexistence.

\footnotetext{
64 "Born in the United States in the 60s and 70s, the Neighborhood Watch arrived in Europe in 1982 from Mollington, Cheshire. The program has been used in countless American and European cities for decades to spread throughout the world. The Neighborhood Control program is applied by more than 10 million families. The program provides for self-organization between neighbors to control the area around their home. This activity is signaled through the placement of appropriate signs ........ A set of small attentions means that the many eyes of those living in the neighborhood represent a credible deterrent for those wishing to perform theft or other forms of crime (graffiti, scammers, scams, vandalism etc.). Collaboration between neighbors is essential for establishing a climate of security that will be perceived by all residents and particularly by the weaker groups such as the elderly and children". https://www.acdv.it/web/index.php/volontari/il-programma
}

\section{Webliography}

www.aawsat.com

www.affaritaliani.it/blog/criminalmente/il profilo psicologico del Combattente del kamikaze Isis-427408. html 15/6/2016.

www.affariitaliani.it: tratto da intervista dottor Mignacca: criminalmente/il profilo psicologico del Combattente del kamikaze Isis-427408.html 15/6/2016.

www.agccommunication.eu: regole di ingaggio/ 6465, article/89, Iraq -Siria -Isis -Baghdadi.

www.agccomunication.eu/ component/ content/ article/ 89- regole di ingaggio/8496- isis - armi - usa.

www.agccommunication.eu: "Profilo di Abu Bakr al-Baghdadi".

www.analisidifesa.it "Mercenari, contractors, Foreign Fighters protagonisti degli odierni conflitti". Pietro Orizio. 24 agosto 2015.

www.azattyq.org

Aranews.org

www.business monitor.com

www.cerchioblu.org: "Belt Bomb children l'uso di bambini come bombe umane" 12 gennaio 2015 Antonella Marchisella.

www.cesnur.org "Tra brainwashing e libera scelta. Per una lettura psicologica dell'affiliazione ai nuovi movimenti religiosi." Mario Aletti, Claudia Alberico.

www.corriere.it Marta Serafini: "Che cos'è e dove viene prodotto il captagon la droga dell'Isis”. 8 maggio 2017.

www.diritto.it: "Il terrorismo islamico e internazionale" Blanda V. 19 ottobre 2006.

www.Facebook.com/ghuraba media

www.gliocchidellaguerra.it: "Così funziona l'esercito dell'Isis" 4 novembre 2016.

www.gremmo.mom.fr Osservazioni di Fabrice Balansh.

huffingtonpost.it: "Wikileaks dell'Isis. I segreti del Califfato svelai da un alto dirigente dello Stato islamico". Daniele Mastrogiacomo 26/09/2014.

www.ilcorriere.it di Raffaella Cagnazzo e Alessandro Fulloni "La strage di Nizza chi era l'autore fermato nel pomeriggio e lasciato andare: consegno gelati”. 16 luglio 2016.

www.ilgiornale.it: "La struttura dell'Isis chi comanda e gli uomini del potere". 18 maggio 2015.

www.ilgiornale.it: "Organizzazione criminale e gerarchie. Islam e mafia eguali sono" 15/12/2015.

www.ilgiornale.it Franco Iacch: "L'evoluzione del terrorismo islamico dai lupi solitari al branco" 26 gennaio 2016.

www.ilgiornale.it: "La strategia linguistica dell'Isis le parole che attivano i martiri" Franco Iacch. 31 marzo 2017.

www.ilgiornale.it: "Così il Qatar finanzia in Italia moschee e scuole coraniche" Sergio Rame 5 giugno.

www.ilfoglio.it: "Come funziona l'Isis? Strutture, organizzazione e controllo del territorio" 26/11/ 2015.

www.ilfoglio.it "I tre tipi di attentati dell'isis che spiegano quanto l'Italia è in pericolo" Alessandro Orsini 29 agosto 2017.

www.ilpost.it: "Al Qaeda ISIS". 21/11/2015.

www.ilpost.it: "Perché sciiti e sunniti litigano" 4 gennaio 2016.

www.ilpost.it:"Non chiamiamoli lupi solitari" 3 aprile 2017.

www.ilpost.it 23 giugno 2017: "Cosa fare dei bambini addestrati dall'Isis".

www.iltempo.it "L'odio nel Corano: combattete chi non crede in Allah" 21 novembre 2015.

it.blastingnews.com. Umberto de Palma: "ISIS: Ecco perché e come punisce la polizia femminile del califfato". 29 dicembre 2015.

www.larepubblica.it. Erica di Blasi: "Mido il terrorista islamico sceglie di collaborare. Arriva anche le FBI per interrogarlo". 2/8/2017. 
www.lastampa.it: "Il vertice dell'Isis in crisi dopo la morte di Al Adnani" 1 settembre 2016.

www.lastampa.it: "A Genova arrestato un terrorista islamico." 19 dicembre 2017.

www.lescienze.it Giovanni Sabato: "Nella mente del terrorista: strategie di prevenzione". 23 aprile 2016.

www lettera43.it: ISIS "La struttura e la catena di comando dei terroristi islamici”. 19/9/2014.

www.lookout.it "Terrorismo: è possibile prevedere gli attentati?" Tiziano Li Piani. 13/5/2017.

m.huffingtonpost.it: "I bambini di Daesh". Martina Pignatti Morano. 1 settembre 2016.

m.huffingtonpost.it: "ISIS: call center, polizia morale, bordelli per jihadisti: essere donna nel califfato islamico". Umberto de Giovannangeli 20/6/2015.

m.huffingtonpost.it: "ISIS da della prostituta a Michelle Obama. Ma la condizione della donna nello stato islamico è agghiacciante". Umberto de Giovannangeli 24/05/2015.

m.huffingtonpost.it Antonella Tarpino: "Nella mente di un terrorista". 4 ottobre 2017.

www.occhidellaguerra.it 2 agosto 2016.

www.occhidellaguerra.it: "Così funziona l'esercito dell'Isis" 4 novembre 2016.

www.panorama.it "Terrorismo il rischio della radicalizzazione in carcere" Nadja Francalacci 8 giugno 2017.

www.panorama.it "Chi sono i reclutatori islamici nelle carceri italiane" Nadia Francalacci 10 gennaio 2017.

www.panorama.it: "Nizza l'immigrazione le periferie e la crescita dell'islam Radicale” Edoardo Frittoli 15 luglio 2016.

www.psicologiaedintorni.wordpress.com: "Il disimpegno morale. I meccanismi di disimpegno morale proposti da Bandura".

Real information. Altervista.org "Le armi adoperate dall'Isis" 4 luglio 2015.

www.redattoresociale.it "Giovani nella morsa già vista così si convincono di essere eletti da Dio" 25 maggio 2016.

www.risveglio nazionale. Wordpress.com "Che cos'è l'Isis e chi sono i suoi mercenari pagati anche $€ 10000$ " 21 febbraio 2015 www.sapere.it "Chi sono I Foreign Fighters".

Correspondence: Monica Calderaro.

E-mail: monica.calderaro@uniroma1.it

Key words: ISIS, Quran, Jihad, Islamic state, Operating Modes/ Propaganda, Profiling, Deradicalization.

Parole chiave: ISIS, Corano, Jihad, stato Islamico, modalità operative/propaganda, profiling, deradicalizzazione.

Palabras clave: ISIS, Corán, Jihad, Estado Islámico, modos de operación/propaganda, profiling, desradicalización.

Conference presentation: Part of this article was presented to the " $1^{\circ}$ Congresso Nazionale dell'Accademia Italiana di Criminologia, Sistema Penale, Investigazioni e Sicurezza" 27-29 April 2018, Rome Italy.

Received for publication: 28 December 2016

Revision received: 26 June 2017.

Accepted for publication: 8 April 2018.

This article is distributed under the terms of the Creative Commons Attribution Noncommercial License (by-nc 4.0) which permits any noncommercial use, distribution, and reproduction in any medium, provided the original author(s) and source are credited.

CCopyright S. Laura, 2018

Licensee PAGEPress, Italy

Rivista di Psicopatologia Forense, Medicina Legale, Criminologia

2018: $23: 21$

doi:10.4081/psyco.2018.21 www.securitysummit.it: CISINT.AGP communication. Workshop daesh cyberwarfare. Dott. A. Albanese Roma 10 giugno 2015.

www.sicurezzaegiustizia.com "Il fenomeno della radicalizzazione violenta e del proselitismo in carcere" di Augusto Zaccariello N. III MMXVI (Profiling dell' estremista violento).

www.studiarapido.it: "Sunniti e sciiti chi sono e l'origine del conflitto".

www.today.it: 'La polizia femminile dell'Isis che tortura e opprime le donne in Siria" 13 luglio 2015.

www.tpi.it: "Ma qual è la mappa del terrorismo 2017?" 20 giugno 2017.

urbeetius.org $>$ uploads $>2017 / 11$ Monique Iandolo, Vincenzo Mastronardi "Il lupo solitario: terrorismo ideologico e religioso nella società liquida".

Waradana.com

\section{References}

A. Albanese, G. Fanciullo, E. Molle, R. Baretsky, G. Balkan, E. Valdenassi. GAP 2014 "The Islamic State. Lo Stato ISLAMICO”.

Albanese, Gangiulo, Molle, Scigliano, Valdenassi. AGP communication. Settembre 2016. "Daesh Matrix" Pag. 86.

Bonanate L. 2001: "Definizione di terrorismo".

Cannavucci M. "PSYOPs. Le operazioni psicologiche nei conflitti asimmetrici”. Giornale di Medicina Militare 2005; 155(4);513-9.

Clinton H. "Hard Choices", Simon \&Shuster, 2014.

D’Auria S. Rassegna penitenziaria e criminologica. 2-2015: "Il terrorismo islamista dalle origini allo stato islamico strategie e normative di contrasto." pag. 81.

De Rosa C. Corriere della Sera ebook 2016 "Nella mente di un jihadista. Per una psicologia dell'Isis".

Direzione Nazionale Antimafia e Antiterrorismo. Relazione annuale sulle attività svolte dal Procuratore nazionale e dalla direzione nazionale antimafia e antiterrorismo nonché sulle dinamiche e strategie della criminalità di tipo mafioso nel periodo primo luglio 2014 - 30 giugno 2015. Pubblicato febbraio 2016.

Flego Loredana, Pomella Antonella, Vincenzo Mastronardi "Profilo criminologico del terrorista homegrown strumenti e tecniche di prevenzione e contrasto al nuovo terrorismo islamico" Rassegna di psicoterapia, ipnosi, medicina psicosomatica, psicopatologia Forense. La Sapienza Università di Roma, volume 20 gennaio aprile 2015 pagina 183 .

Fondazione Ismu: "Ventunesimo rapporto sulle migrazioni 2015 Franco Angeli”. pag. 21-26 Edizioni Digitali.

Mastronardi V. "Moral retreat mechanisms in the formation of the terrorist and Islamic terrorism". Università degli Studi di Roma La Sapienza facoltà di medicina . Department of psychiatry and psycological Medecine. Teaching of forensic psycopathology. Observatory of behaviors and deviance.

Mastronardi V. "Manuale per operatori criminologici e psicopatologi forensi”. Pag. 52-85. 2012 Giuffrè editore.

Oasis n 23 "Il Corano e i suoi custodi". Marsilio editori. 22 giugno 2016 pag. 26.

Palermo G., Mastronardi V. "Il profilo criminologico, dalla scena del crimine ai profili socio psicologici”. Giuffrè Editore 2005.

Romano S. “Anatomia del terrore” edizione Rizzoli 2004 pagina 141.

\section{Filmography}

"STATO ISLAMICO - la nascita di un format". Dalla trasmissione di LA7, Crack Piazza Pulita. 